\title{
DOSTOIEVSKI VERSUS DOSTOIEVSKI
}

\author{
Alí Viquez Jiménez
}

\section{RESUMEN}

\begin{abstract}
Este ensayo realiza una lectura de la obra global de Dostoievski, enfatizando en los problemas éticos y metafísicos planteados en sus cuatro grandes novelas, Crimen y castigo, Los demonios, El príncipe idiota y Los hermanos Karamázov. Pretende hacer patente la posibilidad de leer a Dostoievski más allá de lo que el pensamiento religioso del autor ha querido sugerir, para entender la complejidad de las personalidades de sus personajes principales como un entramado de diversas variables.

Palabras clave: Fiódor Dostoievski, literatura rusa, literatura del siglo XIX, novelas de Dostoievski, humanismo contemporáneo.
\end{abstract}

\begin{abstract}
This essay presents a view of the global work of Dostoyevsky, emphasizing the ethical and metaphysical problems in his four great novels, Crime and Punishment, The Demons, The Idiot, and The Brothers Karamazov. The intention is to make evident the possibility of reading Dostoyevsky beyond the religious thought that the author has wanted to suggest, in order to understand the complexity of the personalities of his main characters through a framework of diverse variables.

Key words: Fyodor Dostoyevsky, Russian Literature, Literature of the nineteenth century, novels of Dostoyevsky, contemporary humanism.
\end{abstract}

Fácil de enunciar, pero mucho más difícil de concretar, mi objetivo a primera vista resulta tan contradictorio como el título que lo antecede. Me propongo demostrar que Dostoievski se equivoca. También me propongo demostrar que Dostoievski acierta.

Más fácil resultaría una repartición de éxitos y fracasos, sucesivos o por trozos. Acierta en esto ahora y yerra en lo otro después; pero no es exactamente eso. Voy a dedicarme a una sola serie de problemas, que de manera consistente atraviesan toda una obra, y que se resuelven

\footnotetext{
Alí Víquez Jiménez. Profesor Catedrático de la Escuela de Filología, Lingüística y Literatura de la Universidad de Costa Rica.

Correo eletrónico: aviquez@yahoo.com
}

Recepción: 15-10-2009

Aceptación: 12-12-2009 
siempre del mismo modo, y voy a plantear que allí se dice verdad y se dice mentira. Pues Dostoievski construye verbalmente un ser humano al que juzga incapaz de sobreponerse a la ausencia de Dios ${ }^{1}$; pero sus personajes, contra todo pronóstico del autor, se yerguen por encima de la suerte que les depara Fiódor Dostoievski en razón de su eventual distanciamiento de la fe o aproximación a esta y demuestran que el autor andaba equivocado. Dostoievski condena a sus personajes a la desesperación metafísica y al infierno moral, a menos que se sepan arrepentir y volver a la religión. Pero también crea personajes capaces de demostrar que esta es una imposición artificiosa, hija de los privilegios de un autor con derecho pleno de ejercerlos, aunque no por eso menos imposición.

Estoy de acuerdo con Bajtín en que la pluralidad de voces que aparece en las novelas de Dostoievski no se ve unificada (vale decir, silenciada) bajo la voz del autor ${ }^{2}$. No pretendo, sin embargo, demostrar lo expuesto en el párrafo anterior con base en la polifonía: no es solamente que las voces se contradigan y que todas tengan su espacio en el texto. Voy más allá. Es cierto que las voces conviven en permanente oposición; es cierto que ninguna se silencia. Pero también es verdad que el autor decide dar un destino a sus personajes que de alguna manera determina el juicio final que estos reciben por sus ideas. Dicho en un caso concreto: Iván Karamázov se explica muy a sus anchas; pero el autor determina, sin haberlo hecho callar, que se vuelva loco e insinúa la probabilidad de su muerte en tan patética condición, y todo esto por causa de su incorregible rechazo del cristianismo. Yo quisiera demostrar que ese autor, tan amigo de escuchar a personajes brillantemente adversos a su credo religioso y político, introduce también una suerte artificiosa en el destino de estos adversarios ${ }^{3}$. Debo probar que esta suerte es artificiosa, en el sentido de que no es más que el resultado de un juicio particular de autor, quien sin embargo es tan hábil que ha logrado crear personajes en los que resulta posible ir más allá de ese limitadísimo resultado final que por ateos los convierte en locos, suicidas o depravados. Dostoievski sabe más que Dostoievski.

Voy a proceder enfrentándome inicialmente a lo que considero son las ideas vencedoras en Dostoievski, en dos ámbitos. El primero, lo llamaré histórico-político; el lector encontrará, no obstante, que hablaré de religión. Se explica fácilmente al tomar en cuenta que la religión es un fenómeno político revestido de aspiraciones metafísicas que con insistencia se olvidan en el curso de la historia, por ejemplo: no aniquilan a los cátaros a causa de las consideraciones teológicas, sino por la oportunidad política y la conveniencia económica. Las teologías triunfantes lo son solo por razones meramente externas a la reflexión teológica. No creo que haga falta aportar aquí pruebas para demostrar un punto tan ejemplificado en la historia de las religiones.

El segundo ámbito es el ético. Aquí pienso dedicarme a combatir el que creo es el error de bulto en el pensamiento de Dostoievski, enunciado en labios de Iván Karamázov, pero presente en todos sus personajes "oscuros": "Si Dios no existe, todo está permitido". Albert Camus ha hecho ya buena parte del camino que planeo seguir.

Aclaro el punto referente a "las ideas vencedoras". No son solo aquellas de las que Dostoievski ha hecho portadores a sus personajes "luminosos"; también. incluyen las ideas que el autor quiso demostrar por medio del infortunio de los "oscuros"4. Pero, como he dicho, el examen de estos dos ámbitos, histórico-político y ético, es solo el punto inicial del trabajo. Después, será necesario volver los ojos a la dinámica en que los personajes de Dostoievski se ven envueltos para conseguir la exposición de esas ideas. Esta es la que considero la sección medular del trabajo, pues si en la parte previa busco demostrar el error de Dostoievski, en 
esta pretendo dar con su acierto a pesar de sí mismo. Las consideraciones finales esbozarán la visualización de este autor desde un saber moderno que no conoció 5 ; hablo de un humanismo actual, derivado de una lectura contemporánea del darwinismo expuesta en nuestro medio por Claudio Gutiérrez ${ }^{6}$.

Dostoievski defiende la supremacía moral de la tradición cristiana rusa frente a los desmanes del catolicismo; esto lo puedo entender de dos maneras: o bien cree que la dirigencia eclesiástica de la ortodoxia rusa evidencia a través de la historia una conducta ejemplar, sin mancha de interés político o conveniencia económica, frente a la corrupción del papado y sus secuaces, o bien piensa que la fe ortodoxa provee a sus fieles de una moral más sólida que la que ha proveído el catolicismo a los suyos. Es decir, o se trata de superioridad moral en el conjunto de las autoridades o de lo mismo en cuanto al pueblo en general. O podría tratarse de ambos: tanto el pueblo como el clero. En todos los casos se equivoca el autor.

No puede sostenerse que la iglesia ortodoxa rusa sea cualitativamente distinta de la católica en su alianza con el poder político. Por un lado, no hace falta revivir la tétrica historia del papado en sus relaciones con los poderes terrenales; por el otro, recordemos, para demostrar la lectura ingenua de la ortodoxia a la que un autor como Dostoievski podría inducirnos, y sin la pretensión de dar más que un somero vistazo, el hecho de que Moscú llegó a ser considerado la "tercera Roma” bajo el reinado de Iván el Terrible (1533-1584) y el cesaropapismo bizantino incluía una fuerte relación iglesia-estado7.

En realidad, la consolidación de la iglesia ortodoxa se da en términos tan políticos como se dio la de la iglesia romana: influyeron la caída de Constantinopla ${ }^{8}$ y sobre todo la liberación del poder de los mongoles en el siglo XV y, desde mucho antes, el cristianismo como tal se había expandido en Rusia a causa del crecimiento de las relaciones comerciales entre rusos y griegos. Se trata de una religión tan adoptada oficialmente como lo fue en su momento el catolicismo: la Iglesia ortodoxa celebró en 1988 su milenario; pues, ¿qué ocurrió en el 988 ? El matrimonio de Vladimir I con la hermana del emperador Basilio II y la imposición de la religión oficial del Imperio Bizantino para el reino de Rus. De manera que cualquier pretensión de "pureza" religiosa al hablar de ortodoxia no es sino una negación de hechos históricos claramente observables 9 .

Otra cosa es que Dostoievski, junto a varias personalidades de la Rusia del siglo XIX, pretendiera un despertar de la religión nacional que la emancipara de lo que se juzgaba por parte de muchos como una influencia nociva del catolicismo y del protestantismo, que sin lugar a dudas se había dado desde tiempos remotos ${ }^{10}$; y para promoverlo se leyera la historia de la ortodoxia rusa como una de pureza religiosa y moral frente a la beligerancia política y la corrupción ética, católicas y protestantes se entiende; pero ello no constituye una verdad sino una plataforma ideológica. Alentada, por cierto, por políticos como el zar Alejandro I, que reformó la enseñanza eclesiástica y alimentó el antioccidentalismo eslavófilo. Por otra parte, en las novelas de Dostoievski no hay ilusiones al respecto de que "en todas partes se cuecen habas" y, así, no dejan de aparecer personajes ligados a la dirigencia ortodoxa que cumplen un papel muy poco piadoso y únicamente se dedican a defender un status quo que los convierte en privilegiados: desde el furioso (y lleno de envidia) padre Ferapont hasta la gran mayoría de los monjes que vivían junto al starets Zosima y se alegran -disimuladamente o no- cuando el cuerpo de este se descompone y hiede antes de lo normal, sin olvidarnos del torcido y ambicioso Rakitín ${ }^{11}$.

En cuanto a la posiblemente genuina percepción de un pueblo ruso en extremo fervoroso por parte de Dostoievski, solo puedo decir que no han faltado españoles que crean 
que su lengua es especial para hablar con Dios, ni franceses que aseguran que a Juana de Arco la guiaba el espíritu santo para salvar a la nación, ni italianos convencidos de que si el papa vive en Roma es por la especial piedad de su país, ni costarricenses sabedores de que la negrita es más virgen que las otras once mil; quiero decir que el juicio de cuál pueblo es el más religioso, en cuál de todos se dan más santos, en qué lugar se está más cerca de Dios, es siempre un juicio donde la nacionalidad de quien lo emite no resulta indiferente. La moral de los ortodoxos y la moral de los católicos, así como la moral de los cristianos y la de los musulmanes, solo puede ser juzgada desde el etnocentrismo, por lo que en cierto sentido más vale abstenerse ${ }^{12}$. En cada pueblo, se percibe a los santos locales como los más santos. Dostoievski no constituye una excepción a esta regla; de hecho, cuando el príncipe Idiota se refiere al tema, da la impresión de que solo le falta llamar al ruso "el pueblo elegido".

Cualquiera se espanta, como Dostoievski, repasando el rosario de pecados que ofrece el catolicismo; que esta haya sido y sea una religión especialmente nociva, probablemente desde su verdadero fundador Pablo de Tarsos, pasando por la Inquisición, los Borgias, Pío XII y un casi interminable etcétera antes del actual jefe Ratzinger, tan deseoso de resucitar el infierno para quienes piensan diferente a él, es algo que yo también soy propenso a pensar. Concedámosle a Dostoievski que la dirigencia de la iglesia ortodoxa rusa tenga las manos mucho menos sucias que el Vaticano; pero no es gran mérito lucir bien si uno se compara con la mafia del papado, es algo de lo que podría ufanarse también el $99,99 \%$ de la humanidad y buena parte de otras religiones, en casi todo el orbe ${ }^{13}$. La iglesia ortodoxa rusa solo se puede considerar un mal menor, pero mal al fin, a menos que aceptemos el razonamiento unamuniano expuesto en el San Manuel Bueno, mártir, y defendamos la expansión de la ignorancia y la aceptación de la falsedad como medios buenos para dar consuelo (vale decir, opio) a los pueblos; que el historial de los ortodoxos sea menos espeluznante que el de los católicos no los convierte en nada diferente de una iglesia más, nacida del interés político y económico, como lo son todas ${ }^{14}$. Si Dostoievski juzgaba esta opción política conveniente para su país, tenía todo el derecho de hacerlo, pero aceptemos que se trató de una propuesta política y no "puramente religiosa": entre gitanos no se deberían leer la mano ${ }^{15}$.

Ahora me interesa discutir con Iván Karamázov. Este viene a formular un dilema trágico que engloba el problema de todos los personajes de Dostoievski que pierden la fe: "Si Dios no existe, todo está permitido". Ante la ausencia de Dios, no hay ley moral absoluta, cada hombre es Dios. Dostoievski solo concibe una moral sólida si esta deriva del poder divino. Pero no solo eso: está seguro de que todos los seres humanos se despeñarán en el abismo de la depravación (destino de Stavroguín, Raskólnikov y el propio Iván, que solo se salva de los extremos por la locura) de no verse contenidos por la ley superior moral de origen divino que, asimismo, les promete la inmortalidad. Sus aseveraciones sobre el odio que prevalecerá entre los hombres en ausencia de Dios son tajantes:

Iván Fiodórovich declaró de modo solemne, durante una discusión, que en toda la tierra no existe absolutamente nada que obligue a los hombres a amar a sus semejantes, que no existe ninguna ley natural que lleve al hombre a amar a la humanidad, y que si hasta ahora ha habido amor en la tierra ello no se debe a ninguna ley natural, sino tan sólo a que la gente creía en su inmortalidad. (Dostoievski 1983: 89)

La refutación de esta tesis la encontramos en Camus, específicamente en los comentarios de la obra de Nietszche que se vierten en El hombre rebelde ${ }^{16}$. Allí se demuestra que Dostoievski precisamente ha formulado la idea al contrario de lo que una reflexión más 
a fondo llega a sugerir: lo que realmente ocurre es que si Dios no existe, entonces nada está permitido ${ }^{17}$. La presencia de Dios, por cierto que muy supuesta, no es más que una justificación imaginaria para la imposición de una moral, siempre relativa e histórica, teñida de intereses particulares, abusiva con el poder que adquiere y negadora de otros puntos de vista. Es una moral que se cree derivada de Dios la que jamás se discute y no admite réplica. Ciertos protestantes norteamericanos pueden invadir países con la justificación de una moral divina, ciertos musulmanes pueden ejercer el terrorismo por la misma razón, los palestinos son masacrados así también. Nietszche y Camus corrigen entonces: los ateos no somos inmorales, pues al darnos cuenta de que Dios no existe, nuestra necesidad de justificar la moral que practicamos se convierte en mayúscula. Creyendo en Dios, eludíamos esa responsabilidad; la moral nos venía derivada de la tradición en que hubiésemos nacido y nuestro único deber consistía en respetarla y llevarla hacia el futuro ${ }^{18}$. Al dejar de creer en Dios, la responsabilidad moral crece, pues cada una de nuestras decisiones éticas no tiene más asidero que el que podamos darle nosotros mismos. Se convierte entonces en una necesidad el racionalizar la ética. Nada más conveniente para una humanidad como la actual; sin embargo, al ver el estado en que se han encontrado recientemente regiones como la franja de Gaza, es necesario admitir que nada parece más lejano ${ }^{19}$.

Pero hay algo más, que yo quisiera agregar acá y no proviene de Albert Camus. Dostoievski plantea un tipo de razonamiento vulgar que se detecta en muchos de quienes, aún albergando severas dudas en torno a la existencia de Dios, sostienen que es necesario creer en ella, pues de lo contrario la humanidad se desbocaría en el ejercicio del mal. "Si yo no creyera en Dios, andaría robando y matando gente", me confesó alguna vez un individuo de sonrisa perturbadora, de quien me alejé velozmente, antes de que se diera cuenta de la verdad. No puedo evitar pensar que Dostoievski plantea que todo el mundo anhela convertirse en el vicioso Fiódor Karamázov allá en el fondo de su corazón y de otros sitios menos santos de su anatomía, y que solo la religión lo disuade de tal. Y tampoco puedo evitar el paso siguiente: entonces lo que aleja al ser humano de los repugnantes vicios que el viejo Karamázov exhibe sin vergüenza alguna, no es más que la amenaza del castigo que provendrá de Dios.

La idea, en primer lugar, me parece indigna de la estatura de un autor como el que crítico. Nada cambia entre la forma de pensar del tosco Tirso de Molina y del perspicaz Dostoievski; en ambos casos, el dedo admonitor señala que habrá castigo para quienes se separen de la moral de Dios padre. La única diferencia es que Tirso provee el castigo después de la muerte, mientras que Dostoievski lo instituye en la tragedia vivida en este mundo. Si se quiere, al menos Tirso lo fiaba para más largo.

Esta elección de una moral no encuentra entonces su asidero en la convicción personal de quien decide que una acción es buena y recomendable por lo que ella es, sino en el brazo que Dios o más bien su autoproclamado lugarteniente, la autoridad religiosa, nos tuerce con su amenaza. Dostoievski razona como esos padres, esos maestros, esos militares, esos políticos seguros de que una línea de conducta solo se cumple si se acompaña de un tortazo o de un severo aviso de la inminencia de este; más aún, Dostoievski está seguro de la propensión del ser humano al egoísmo más descontrolado y nocivo: solo dejamos de ser asesinos despiadados o depredadores sexuales porque tememos un castigo. Habría que corregir su advertencia: él no cree que el hombre se convierte en Dios si este no existe: cree que se transforma en el mismísimo diablo ${ }^{20}$. 
Repito que tal precariedad de pensamiento me disgusta en un autor de la talla de Dostoievski. Pero mi intención es demostrar que esto es solo una cara de la moneda. Este es el Dostoievski que se equivoca: no quiero caer en los psicologismos, pero aquí no veo más que al niño asustado ante el padre abusivo que fantasea con tomar su lugar, y al mismo tiempo teme lo que podría llegar a ser él mismo si tal cambio se generase ${ }^{21}$. Un deseo de venganza se contiene confusamente ante el horror de tornarse en peor aún que el enemigo odiado. El hijo esclavizado no pretende derrocar al padre para acabar con la esclavitud, más bien para ejercerla poniéndose él en el rol del amo. El don Juan en su peor faceta, la del vicioso que no sabe amar, se esconde en todos los hombres 22 .

Se trata de un Dostoievski primitivo que persiste, pero que se corrige por la fuerza de su conocimiento más profundo del ser humano; quizá, al llegar a este punto habría que enunciarlo así: Dostoievski el artista observador (se pretende un realista, ya lo hemos visto ${ }^{23}$ ) sabe mucho más que Dostoievski el religioso moralista. Pues veamos lo que sus personajes tienen que decirnos acerca de la idea del todo está permitido en ausencia de Dios, quiero decir: veamos lo que dicen y veamos lo que hacen ${ }^{24}$.

Comencemos observando a uno de sus personajes, que se salva, pero por muy poco, de la perdición: Raskólnikov. O, más bien, que se cura de ella. No voy a repetir aquí su discurso no escasamente pueril, según el cual logró visualizar su propia imagen como la de un nuevo Napoleón. Al fin, las locas y tontas fantasías de grandeza alimentadas acerca de uno mismo todos las hemos tenido en la primera juventud; la única diferencia en el caso de Raskólnikov es que él se dejó dominar por ellas ${ }^{25}$. Se me dirá que esto no es poco disparate, y lo admito. Pero existe una insigne tradición. El primero en cometer la locura de creer que las palabras vertidas en el interior de nuestra mente pueden asimismo vertirse, como por arte de magia, en la realidad, es don Quijote; Raskólnikov sufre de esta misma clase de espejismo. Alonso Quijano sale a los caminos para probar con los actos la verdad de esas íntimas palabras, las cuales perseverarán en deslizarse de su mente a los oídos de los demás ${ }^{26}$; Raskólnikov, menos seguro, menos autoengañado, pretende probarse primero a sí mismo -con un acto del cual nadie se enterará- la verdad de su ilusión. Lo que Raskólnikov se propone realizar es un crimen privado, que vendría a confirmarle su grandeza napoleónica, antes de dar la cara frente a los demás, ahora sí completamente convencido de ser quien imagina ser ${ }^{27}$.

Ahora bien, el mayor problema para Raskólnikov estriba, a mi modo de ver, en que su fantasía lo divorcia de sus propias convicciones éticas. No estableceré cuáles son estas convicciones con base en su errático discurso, sino más bien por medio de la conducta del personaje. Lo que quiero decir es que Raskólnikov se conduce, antes y después de su crimen "de prueba", de una forma completamente apegada a los valores (cristianos, si se quiere, pero no exclusivamente) de la caridad y la solidaridad; de hecho, por ello obtiene una disminución de su castigo: su amigo Rasumikhine ${ }^{28}$ demuestra que "[...] el asesino Raskólnikov se había repartido por espacio de seis meses sus escasos recursos, hasta el último kopek, con un compañero necesitado y tuberculoso. Cuando este murió, Raskólnikov prestó toda la ayuda posible al padre del difunto [...]" (1981: 546). La viuda de Zarnitzine “[...] dijo que en la época en que vivía en las Cinco Esquinas, teniendo a Raskólnikov como huésped, una noche se había declarado un incendio en la casa vecina, y su pupilo, con peligro de perder la vida, había salvado a dos niños de las llamas, sufriendo algunas quemaduras" (1981: 546-547). Esto sin hablar de la conducta de Raskólnikov hacia Sonia y su familia, en relación con la cual no se puede aducir que hubiera algún interés erótico del benefactor, puesto que entre ellos no surge nada remotamente romántico sino hasta después de que han comenzado los actos generosos y solidarios de Raskólnikov. 
De modo que, al igual que en el caso de don Quijote $^{29}$, el personaje ya actuaba movido por ciertos valores, independientemente de lo que su perturbador discurso seudo napoleónico le hiciera pensar. Creer que Raskólnikov adquiere una ética de solidaridad y amor al prójimo apenas al final de la novela, cuando se "regenera" en el cristianismo, es algo fundamentalmente erróneo. El discurso religioso a lo sumo pudo proveerlo de una justificación conceptual de lo que ya era una elección, una orientación ética prevaleciente en él, y esto ni siquiera lo sabemos con seguridad puesto que a estas alturas el personaje no se escucha, solo el narrador. Raskólnikov no adquiere valores gracias al cristianismo, ya los tenía cuando se hizo cristiano; por ello, Dostoievski se encontraba equivocado si pensó que Raskólnikov se salvaba al hacerse cristiano: el personaje confiesa su crimen no porque lo atormentara el haber desobedecido a un Dios que -al menos hasta el momento de la confesión- lo tiene muy sin cuidado, sino porque rechaza la posibilidad de una vida (y de una muerte) lanzadas al abismo de la depravación por la falta de solidaridad ${ }^{30}$.

Es decir que, según nos lo ha enseñado Camus, el ser humano es capaz de abrazar valores por lo que estos valen en sí mismos, no por lo que un Dios ruja. El hecho de que Raskólnikov se convierta al cristianismo solo responde a un prejuicio del autor: sus valores y su conducta habrían sido similares al final del texto si hubiera seguido siendo ateo. Y voy más allá: así como Dostoievski caricaturiza las fantasías de grandeza de Raskólnikov -pues se trata de esto ni más ni menos, de lo contrario habría podido enriquecer al personaje haciéndolo defensor de algún tipo de teoría política como sustrato de sus ansías por sobresalir-, también se puede degradar la práctica de la religión cristiana, por la vía de su reducción a lo que tiene de más repulsivo.

En una aguda objeción al pensamiento de Richard Dawkins, Terry Eagleton lo acusa de atacar la religión valiéndose solamente de las versiones deplorables de esta:

\footnotetext{
[...] gran parte del ateísmo hoy día es solo religión invertida. Los ateos suelen anticipar una versión de la religión que nadie en su sano juicio suscribiría, y después, con razón, la rechazan. Aceptan el tipo de estereotipos burdos de ella que sin duda les horrorizarían en cualquier otro campo del conocimiento académico. [...] Un ateo confeso como Richard Dawkins es en este aspecto la mera imagen invertida de Ian Paisley. [...] El verdadero reto es construir una versión de la religión que realmente valga la pena rechazar. Y esto tiene que empezar por rebatir el mejor ejemplo del oponente, no el peor. (2005: 183-184)
}

El argumento es válido, pero solo en tanto no se tome en cuenta que, históricamente, las religiones con demasiada frecuencia han sabido presentarse en la peor de sus facetas, y que en efecto hay una gran cantidad de personas en el mundo que parecen no estar en su sano juicio cuando actúan movidas por la religión. Dawkins no hace sino enfrentarse a la cruda realidad, Eagleton querría que hasta cierto punto se la idealizase. Por otro lado, y en relación con lo que propiamente nos ocupa, la presentación de la peor faceta del catolicismo es lo que hará Dostoievski con la creación de la figura del Gran Inquisidor ${ }^{31}$; otro tanto puede decirse de su versión de los revolucionarios rusos en Los Demonios y, obviamente, como ya he señalado, es lo que ha hecho con Raskólnikov, a quien dota de nada más que de un pobre afán de ser líder, sin una sola idea aparte de sus tremendas ganas. La objeción de Eagleton a Dawkins también se le podría efectuar a Dostoievski, mutatis mutandi.

Veamos ahora el caso del príncipe Mishkin. Queda claro que el personaje tiene un fin paupérrimo: de vuelta al estado de idiotismo menos esperanzador, de nada le valió su poderosa fe en el cristianismo ortodoxo ruso. Se trata aquí de que la fuerza de los acontecimientos externos e internos excede la de cualquier orientación ideológica en el personaje. El príncipe 
puede cacarear a su gusto toda la grandeza de la iglesia rusa durante buena parte del libro y -lo que ha de admitirse como mucho más importante y meritorio- puede actuar apegado a sus valores de cristiano ejemplar; a la hora de enfrentarse a la realidad, estas decisiones son apenas más que futilidades. La realidad, el destino final de los personajes, se mueve en otro plano. El príncipe es idiota por algo relacionado con su naturaleza profunda, que Dostoievski no conoce y no describe, pero al menos percibe y respeta. Si nos salváramos porque somos cristianos y nos condenáramos por dejar de serlo, el destino del príncipe idiota no se podría explicar. Dostoievski es demasiado buen escritor como para torcer de un modo satisfactorio para su propia visión de mundo el destino de un personaje: antes presenta la realidad, aunque le duela. Dostoievski acierta aunque se equivoque.

Por otro lado, se podría objetar que en el príncipe Mishkin se encuentra una especie de alegoría del mártir cristiano; de una manera posterior a la muerte, su sacrificio espera recompensa. "Tan largo me lo fiáis..." es lo primero por argüir, y es contundente: ¿qué clase de solidez ofrece una especulación tan rotundamente imaginaria? Ahora bien, lo cierto es que la figura evocada en el texto a propósito de Mishkin es don Quijote ${ }^{32}$ y no Cristo, pero admitamos la posibilidad, ya que tampoco falta quien ve en don Quijote a un santo cristiano ${ }^{33}$. Dos consideraciones formularé: en primer lugar, los resultados de las intervenciones de este "bendito" son lamentables 34 ; si Dostoievski quería retratar a un santo, este es uno al que es mejor no arrimarse. En segundo lugar, su condición de "idiota" es innegable: ¿quiere esto decir que el mejor cristiano es el más lelo? ${ }^{35}$ Pues flaco favor le hace esta postura a la religión cristiana: así las cosas, no queda más que reservarse con fiereza el derecho de no querer pertenecer a un grupo que hace de la imbecilidad una virtud ${ }^{36}$.

Antes hablé de los acontecimientos exteriores e interiores que mueven al príncipe de vuelta al idiotismo profundo ${ }^{37}$. Sobre estos últimos, ya he hecho ver que Dostoievski se mantiene reservado: la cuestión propiamente patológica no es su especialidad, por mucho que sea un maestro inigualable en la descripción de personalidades enfermas; quiero decir que Dostoievski conoce los síntomas, no las etiologías. En cuanto a los acontecimientos exteriores, el empujón final del príncipe hacia los abismos de la enfermedad mental lo constituye el asesinato de Natasha Filipovna a manos de Rogoyín. La experiencia en la que Mishkin se ve envuelto hubiera resultado de por sí traumática para cualquiera, con mucha más razón para alguien tan débil de mente como él: luego de liquidar a su amada, Rogoyín hace que el príncipe lo acompañe toda la noche al lado del cadáver todavía adorado, aunque ya fuente de un hedor putrefacto.

Y este Rogoyín, ¿acaso es un monstruo porque es ateo? Pues no. En primer lugar, Rogoyín no es un monstruo: es alguien que comete un acto monstruoso movido por una pasión incontrolable ${ }^{38}$. En cuanto a las creencias religiosas o a su ausencia en este personaje, es notable el hecho de que el propio Rogoyín llega a saber que una orientación filosófica o religiosa es lo de menos a la hora de actuar movido por la pasión: da igual si se es ateo o creyente. La escena en la que Rogoyín intercambia su cruz con la del príncipe resulta especialmente significativa, pues en ella el primero se da cuenta conscientemente (valga la redundancia) de que a la hora de actuar la pasión no se deja aconsejar por la postura religiosa ${ }^{39}$.

Es Mishkin quien, en el transcurso de este pasaje, hace ver que la rectitud de la conducta tampoco se relaciona con la creencia religiosa. El ateo del cuento que le narra a Rogoyín observa un comportamiento ejemplar, mientras que el creyente degüella a su prójimo no sin antes pedir perdón a Dios. Según el idiota, esto en parte demuestra que la razón es incapaz de elevarse hasta comprender la esencia del sentimiento religioso, el cual puede brotar 
con fuerza hasta en los corazones más viles. Es una forma de verlo muy cuestionable: lo que verdaderamente demuestra el episodio, es que la creencia en Dios -y este es un ejemplo de la ficción al que podrían sumársele mil de la historia del mundo- ha servido para tranquilizar la conciencia de aquellos que cometen los actos más atroces, y después (o incluso antes, como es el caso en el texto) hallan muy cómodo pedirle perdón a su Dios y todo listo, el que peca y reza empata: quedan mágicamente eximidos de culpa en su torcida conciencia ${ }^{40}$.

Todavía vale la pena una palabra sobre Ippolit, otro personaje con quien se relaciona el príncipe idiota. Este curioso muchacho está desahuciado por causa de la tuberculosis y su muerte se verifica quince días después del asesinato de Natasha Filipovna. Es una de esas personalidades complejas que el genio de Dostoievski sabe retratar en sus numerosas contradicciones: cruel y bondadoso a la vez, parece depender de la opinión de todos y a la vez nada le importa ya, pues conoce la proximidad de su deceso. Llora al pensar que alguien pueda creerlo un cobarde, cuando fracasa en su intento en apariencia auténtico de suicidarse de una forma sin embargo harto espectacular para ser viable, como un solemne esclavo del qué dirán incluso en el lecho de muerte, al tiempo que se burla de todos a su alrededor y repetidamente los manda a freír churros. Aprende a apreciar la enormidad existencial del momento presente, que es eterno mientras dura, como ha dicho Vinicio de Moraes acerca del amor, y sabe que por esta inmensa dimensión oculta en el momento presente lograríamos no necesitar el consuelo de la vida futura, pero por otro lado confiesa que "[...] a pesar de todos mis esfuerzos nunca he podido imaginarme que la vida futura y la Providencia no existen." (2004: 437). Desprecia el culto del príncipe porque este justifica la existencia de la muerte: "(el príncipe) en sus argumentos cristianos llegará sin duda a la venturosa idea de que, en realidad, lo mejor es que se muera uno. (Los cristianos como él siempre llegan a esa conclusión; es su idea favorita)" (2004: 436). Vale decir que Ippolit es un personaje capaz de ejemplificar que, aunque racionalmente se pueda rechazar la religión, el ligamen irracional que uno puede desarrollar con ella corre el riesgo de ser irrompible ${ }^{41}$. Después de esto, yo solo logro pensar que si Dostoievski no quería desautorizar al cristianismo con un personaje como Ippolit, entonces no sé qué deseaba. Lo curioso es que al parecer, no lo deseaba. Acertó en la creación del personaje, aunque él lograra mantenerse pertinazmente equivocado.

De Fiódor Karamázov se dice que era malo y sentimental (1983: 37). Hay en el carácter de este personaje una emotividad a flor de piel que hace de su maldad una suerte de atributo exhibido sin pudor. Resulta obvio que el padre de los Karamázov es malo, y no porque sea sincero (es un embustero consuetudinario, de quien se conoce que montaba comedias hasta en desmedro de sus propios intereses ${ }^{42}$ ), sino porque le resulta imposible que sus sentimientos no se manifiesten. Su amor por el repugnante rol del payaso solo se ve igualado por su lujuria ilimitada; de manera que, cuando le llega el momento de preguntarse si Dios en verdad existe (más bien tarde en su vida, siendo ya un hombre maduro y de hecho poquísimo antes de su violento deceso), hay en la pregunta un trasfondo de maldad y lujuria que resultan transparentes: Fiódor Karamázov pretende averiguar si recibirá algún tipo de castigo divino por lanzarse sobre Grúshenka, la mujer a la que ama su hijo Dimitri. Procede, por cierto, más como un hijo que como un padre, ya que le pregunta a sus propios vástagos, Iván y Aliosha, cuál es la verdad sobre el asunto teológico: Iván le responde que no existe Dios y que la inmortalidad asimismo es una esperanza vana, mientras que Aliosha le asegura todo lo contrario. Inmediatamente toma una decisión, si bien no poco etílica, el padre: "Hum. Lo más probable es que tenga razón Iván" (1983: 169); así, siente autorizada su lúbrica voracidad. 
Ahora bien, lo que demuestra todo el episodio es que a Fiódor Karamázov la cuestión teológica lo tiene muy sin cuidado. La lujuria y la maldad que lo mueven no le permiten interesarse genuinamente en algo así. Si en este caso se siente más a gusto pensando que tras sus malos actos no lo aguarda el castigo post mortem, eso no quiere decir que no los habría cometido de suponer que sí lo hay. De hecho, él lleva toda una vida de perversidades a sus espaldas para cuando conversa de esto con sus hijos, y todo parece indicar que ha creído en Dios hasta entonces, si bien de una forma primitiva y acomodaticia ${ }^{43}$. De manera que pensar que el viejo Karamázov se hubiera abstenido del mal en caso de creer en Dios y peca por cuanto ya no cree en Dios constituye una ingenuidad sin límites, que Dostoievski es el primero en hacernos notar. Lo más probable es que si los dos hijos de este personaje le hubieran asegurado que Dios existía, de idéntico modo se habría lanzando sobre Grúshenka, solo que pidiéndole perdón por sus actos a la Divinidad. ¿Se allana su camino final hacia el mal porque ya no debe perder el tiempo con fingidos arrepentimientos? Quién sabe, recuérdese que para su patético histrionismo las payasadas de lamentación posterior le suelen agregar sal al platillo erótico.

El punto aquí es que tanto el padre, un rapaz incontinente, como su asesino, el hijo no reconocido, Smerdiákov, cometen sus crímenes con independencia de su credo religioso. Este último acepta la máxima de Iván, "todo está permitido", que interpreta como una luz verde para liquidar al viejo, mas sin necesidad de pasar por la premisa que la justifica: "si Dios no existe". Smerdiákov cree en Dios, pero esto le parece "independiente" de lo que Iván está diciendo; después de todo, Iván es el señor, es quien posee la inteligencia para autorizar el asesinato: “....usted (Iván) estaba al corriente de lo que se preparaba, me encargó matar y sabiéndolo todo se marchó” (1983: 754). No debería pasarse por alto el hecho contundente de que el asesinato que da lugar a la narración se motiva y se comete con mucha independencia de la discusión filosófica. El asunto de si Dios existe o no existe finalmente no se torna determinante en relación con por qué se mata, a quién se mata y quién mata. La ética y la conducta de los seres humanos demuestran aquí también que no encuentran su arraigo en la religión o en la carencia de esta ${ }^{44}$. Dostoievski hace ver que la discusión filosófica está ahí, rondando, y quizá sea muy importante para personajes como Iván y Aliosha, pero no es medular en el accionar y en la vida de quienes finalmente motivan y ejecutan las decisiones tomadas, como Fiódor Karamázov o Smerdiákov. Dostoievski conoce demasiado bien al ser humano como para presentar en la novela que otra cosa podría ser; acierta de nuevo, y persiste en el error de ver en la fe una fuente de bondad.

Examinaré al resto de los hermanos, los legítimos, cuya implicación en el asesinato es de hecho menor. Aliosha, el bondadoso Aliosha, ¿acaso es casi un ángel por causa de su fe en Dios? Nada más alejado de la verdad, y ello se nos demuestra desde la primera impresión que se nos da del personaje:

\footnotetext{
Ante todo diré que este joven, Aliosha, no era en modo alguno un fanático, ni siquiera, por lo menos a mi modo de ver, un místico. Daré a conocer desde el primer momento mi opinión completa: era, simplemente, un filántropo precoz, y si se había lanzado por la senda de la vida monacal se debía tan sólo a que, en aquel entonces, dicho camino era el único que le había impresionado algo [...]. (1983: 28-29)
}

En Aliosha, se conjuga esta primigenia inclinación a amar al prójimo con una especie de recato erótico rotundo: su castidad se califica de feroz (1983: 31); de manera que, por esta vía, llega a la religión teniendo ya la inclinación a la clase de virtudes que el cristianismo ha solido impulsar ${ }^{45}$. Se me objetará con razón que Dostoievski de forma explícita renuncia en el caso de Aliosha a la pretensión de hacerlo un creyente primero y un personaje bondadoso después. 
Pero el asunto que traigo entre manos es este: más bien resulta que Aliosha es un personaje en quien la bondad se mantiene inalterable pese a su orientación religiosa. Es ante Aliosha que presenta Iván su rechazo tajante del plan de Dios por cuanto este incluye el sufrimiento de los niños ${ }^{46}$. Cuando es interpelado acerca de si está dispuesto a asumir el rol de arquitecto de un universo que destina a los niños el dolor, también Aliosha responde que no, como Iván; si enseguida argumenta que Jesucristo es quien puede perdonar por ese sufrimiento, porque se ha sacrificado por todos, ello no lo conduce a ninguna objeción lógica de los argumentos de su hermano: no está nada claro cómo Dios, el arquitecto de un destino lleno de sufrimiento para muchos inocentes, puede ser también quien perdone, solo porque se ha destinado a sí mismo también parte de ese dolor. ¿Se está Dios perdonando a sí mismo en razón de haberse autoinfligido un castigo? Aun así, la objeción de Iván no se ha refutado: ¿por qué, en cualquier caso, Dios ha ideado un universo lleno de dolor para quienes no se lo merecen? En otras palabras, y con toda crudeza, el hecho de que Dios tenga propensión al masoquismo no le justifica su sadismo ${ }^{47}$.

Admítase entonces que Aliosha permanece en la religión más allá de cualquier razonamiento, de una manera incluso bastante ciega. No le cuestionaré al personaje su innegable bondad, manifiesta tiernamente en el caso de Iliúshechka, con la narración de cuyo entierro se cierra el libro, y que sin duda consigue evocar que lo bueno existe en todos los seres humanos de manera primigenia, opinión quizá cuestionable mas en cualquier caso hermosa y hasta laudable ${ }^{48}$. Pero debe aceptarse que en el personaje está arraigado un apego a lo irracional, y que esta suerte de vitalismo ilógico es el que logra que Aliosha no se desgarre como su hermano ante las contradicciones de la creencia religiosa:

\footnotetext{
- Creo que lo primero que se debe amar en este mundo es la vida.

- ¿Amar la vida más que su sentido?

- Sin duda alguna, amar la vida antes que la lógica... (1983: 284) ${ }^{49}$.
}

Es justo lanzar también la mirada sobre Dimitri, el hermano más primitivo de los tres legítimos, pero no por eso completamente ausente de estos problemas filosóficos. Debe tenerse presente que su relación con la discusión teológica se da en medio de un acaloramiento karamazoviano que nunca lo deja en paz. Dimitri es aquel en quien el apellido más pesa; su naturaleza tumultuosa no le permite calmarse, su carácter es tan fácilmente irascible como rápidamente tranquilizable. Muchas de las personas a su alrededor, sin necesidad de ser muy dotadas, perciben cómo es verdaderamente. Dice Andrei, el cochero, cuando Dimitri lo interroga burdamente sobre si cree que por pecador él (Dimitri) habrá de ir al infierno: “[...] en nuestra ciudad, señor, usted es como una criatura... así por lo menos lo consideramos... Y aunque monta usted en cólera con facilidad, señor, y esto no se puede negar, Dios le perdonará porque tiene usted un natural bondadoso" (1983: 501).

Dimitri continúa siendo un niño que se imagina el infierno y a Dios de la manera menos elaborada, solo que un niño que sería capaz de matar en un arranque de celos, un niño dominado por la pasión erótica. Cuando escucha el "todo está permitido" de Iván, sí lo hace comprendiendo que este es consecuencia del ateísmo, pero si algún interés encuentra en ello es porque arde en deseos de proceder contra su padre ${ }^{50}$. Dimitri se hubiera agarrado de lo que fuera con tal de sentirse autorizado a pelear por su Grúshenka, el ateísmo no significa para él nada en lo que haya reflexionado; sus impulsos más bien lo llevan al amor no tanto de la Divinidad, una abstracción que tampoco comprende, sino del dios ruso, que implica 
una forma de vida concreta. Es así como lo declara, al final, ya convicto injustamente por el crimen que ha cometido Smerdiákov51: "¡Yo amo a Rusia, Alexei, amo al dios ruso, aunque sea yo un canalla!" (1983: 920). En su rudimentaria comprensión de las cosas, y en su bondad salvaje, Dimitri Karamázov no duda en culparse a sí mismo antes que buscar en los demás la causa de su perdición. He aquí un alma simple, que no podía comprender cabalmente a Iván.

Por cierto, que a este el Diablo lo visita; la alucinación se identifica como tal por parte de Iván ${ }^{52}$, la conversación, sin embargo, continúa. Y es que hay un asunto que Camus ha subrayado en el caso de Iván: este no es originalmente ateo, más bien cree que Dios no merece existir, y por eso dice que no existe; pero es un agnóstico, para quien la existencia de Dios no está comprobada ni está negada ${ }^{53}$. De paso, tampoco la del Diablo. Por ello se permite frecuentar escenarios en los que Dios existe, y desarrolla allí diversos razonamientos. Debe recordarse que el Gran Inquisidor está dando su discurso frente a Jesucristo, cuya segunda venida se ha concretado en el escenario que Iván imagina, la España del siglo XVI; por ello -aunque mal de su grado- Iván tolera también visitas del Diablo.

Dado que lo que Iván hace es construir escenarios en los que se desarrollan diversos tipos de posibilidades filosóficas, no me queda más que definirlo como un intelectual. Y como suele ocurrir en estos casos, es incapaz ya no de actuar (Iván jamás hubiera matado al viejo Karamázov, por mucho que lo deseara) sino también de advertir a tiempo el plan de Smerdiákov de asesinar al viejo Karamázov. Para ser un personaje inteligente, resulta notable lo despacito que debe explicarle Smerdiákov por qué este se sintió autorizado por Iván para cometer el crimen: serán necesarias tres visitas. Iván, tan sagaz en el papel, se comporta con muy pocas luces cuando de realidad se trata. Lo dicho: un intelectual.

Lo que mejor retrata a Iván no es tanto su poema del Gran Inquisidor. Este expresa su pensamiento, pero no a su persona por entero. Pues recuérdese que Iván no está dispuesto a dejar de vivir, aunque no tenga ya motivación alguna, sino hasta cumplir los treinta años. Lo mueve el mero impulso vital karamazoviano, que está tan lejos de la reflexión filosófica en el caso de Iván como en el de Dimitri o de Fiódor Karamázov. Es en el fondo mera lujuria: recuérdese que Iván no anda menos activo en el departamento amoroso que sus dos parientes, aunque proceda (lo cual no es difícil) con mayores decoro y pudor que ellos. Pero por mucho que se ría de sí mismo o se desprecie brutalmente al verse en tal situación, Katerina Ivánovna lo sigue trayendo de las narices.

Así que la pregunta de si Iván se vuelve loco, acaso se muere ${ }^{54}$, por causa de su ateísmo, pierde validez, en primer lugar, porque Iván es más agnóstico que ateo. Cuando comprende que su participación en el asesinato del padre ha sido significativa, pues le dio luz verde a Smerdiákov, también comprende los alcances que puede llegar a tener el "todo está permitido". No negaré que él sí percibe que sus ideas filosóficas han intervenido en el hecho de que se haya llegado tan lejos, pero también debe admitirse que, mientras la violencia podía prevenirse, Iván nunca fue consciente de tal. Lo que quiero decir es que Iván no desarrolló ni toleró con plena conciencia un plan para asesinar a su padre, dado que Dios no existe y todo está permitido. En primer lugar, él no está seguro de que Dios no exista; en segundo lugar, él no se da cuenta de lo que está tramando Smerdiákov; en tercer lugar, si en el fondo deseaba la muerte del padre, nunca se lo había confesado a sí mismo abiertamente. Cuando Iván admite que anhelaba la muerte del viejo Karamázov, también pretende que la muerte del padre la deseamos todos, y así lo dice ante el jurado que juzga a Dimitri ${ }^{55}$. 


\begin{abstract}
-[...] fue él (Smerdiákov) quien mató a mi padre, y no mi hermano. Fue él quien mató, y yo le enseñé a matar... ¿Quién no desea la muerte de su padre?

- ¿Está usted en su sano juicio? -soltó el presidente, a pesar suyo.

-Esa es la cuestión, que estoy en mi juicio... y en un vil juicio, exactamente igual que usted y todos esos... ¡ carotas! -de pronto se volvió hacia el público-. Han matado al padre y hacen como si estuvieran asustados -reclamó con maligno desdén-. Unos con otros fingen. ¡Embusteros! Todos desean la muerte del padre. Una alimaña se come a otra alimaña...”. (1983: 825)
\end{abstract}

Si después Iván enloquece, quizás se muere, es porque no soporta haber deseado la muerte del padre, que se verifica, y esto es independiente de lo que ha elaborado como postura filosófica. Él ha impulsado, de manera ciega, a Smerdiákov, debido a esa postura filosófica, pero ello es mera casualidad. Lo que lo atormenta y lo enferma no es esa coincidencia, sino el deseo profundo de cometer parricidio que descubre en el fondo de su ser; de no haber soltado en presencia del bastardo su fórmula del "todo está permitido", ello no le habría impedido impulsar de algún otro modo el asesinato, puesto que el deseo iba a estar allí de todos modos. Es un error creer que hay una causa filosófica (Iván razona que Dios no existe y todo está permitido) y un efecto concreto (Smerdiákov se sabe autorizado para matar al padre y lo hace); más bien hay una causa profunda (Iván y Smerdiákov desean la muerte del padre), un primer efecto (Iván, valiéndose de una fórmula filosófica, como se hubiera podido valer de cualquier otra cosa, autoriza a Smerdiákov para que mate al padre) y un segundo efecto derivado del primero (el asesinato se comete). El texto deja esto como evidencia, independientemente de lo que fuere la opinión probablemente equivocada del autor.

Mucho menos hesitante que Iván, el misterioso protagonista de Los Demonios, el malhadado Stavroguín, sí que termina por ser ateo. Ha sometido a prueba la existencia de Dios, y ha hallado que este no existe ${ }^{56}$; además, es mucho más valiente que Karamázov, no teme llegar a los extremos de la depravación ${ }^{57}$. Ahora bien, aparentemente Stavroguín no ha sido siempre ateo; por el contrario, sabemos que antes en su vida él ha externado una serie de opiniones (qué tan sinceras, es algo que permanece sin aclararse) que bien podría suscribir el nada perverso príncipe idiota: creía que el catolicismo romano había roto con el verdadero espíritu del cristianismo y que solo se podía ser ruso si se era fiel practicante del cristianismo ortodoxo ${ }^{58}$. Es en relación con el caso de Stavroguín que se escucha lo siguiente: “[...] si alguien le demostrase matemáticamente que la verdad residía fuera de Cristo, preferiría quedarse con Cristo antes que con la verdad" (1980: 265). Esta es una idea que también se encuentra, asumida por el autor, en el Diario de un escritor.

Nada hay que obligue a pensar que la depravación de Stavroguín ha comenzado luego de que abandonara el credo que aquí he identificado con el del príncipe Mishkin²5; más bien, todas esas ideas y esos actos se confunden en un pasado no poco difuso, que el personaje mismo no llega a confirmar más que parcialmente. Lo que ocurre con Stavroguín es, según su propia confesión, que cree carecer de conciencia moral: “...no conozco ni siento el bien y el mal, y no se trata sólo de haber perdido la sensibilidad para ello, sino, además, de que ni el bien ni el mal existen (esto me resultaba agradable), existen sólo unos prejuicios..." (1980: 743). Esto no le acaece por ser ateo: es que, desde siempre, ha tendido a estar hastiado de la existencia y ha necesitado llenarla con algo, que ha sido la depravación, y lo ha hecho pensando como ateo y pensando como el príncipe Mishkin: "Vivir se me hacía insoportablemente aburrido, esto era lo principal" (1980: 744). No hay por qué suponer que no era sincero cuando externó pareceres similares a los del príncipe Mishkin, si paralelamente llevaba esa vida desordenada: que Dios exista o no nada cambia en relación con el hecho de morir de tedio y dedicarse a remediar esto ${ }^{60}$; que la religión ortodoxa sea necesaria para Rusia o no lo sea, nada cambia en relación con el vacío fundamental de la vida. 
Cuando Stavroguín llega al arrepentimiento es porque entiende que ha pasado un límite que no debió haber franqueado; pero, ¿se suicida porque comprende que con el abuso de menores ha infringido la ley de Dios? No es así. Se suicida porque sabe que ha ido más allá de lo que sus propios valores, existentes aunque laxos y aunque él los creyera inexistentes, le permitían. ¿No hubiera llegado tan lejos de haber tenido eso que los creyentes valoran llamándolo "temor de Dios"? Quizás, pero tampoco lo hubiera hecho de haber sabido lo que Camus señala: el ateísmo nos compromete más con la justificación de los valores de lo que ha podido comprometer jamás una religión.

Por lo tanto, no es necesario pensar en Stavroguín como en alguien que cae en el abismo por la falta de fe. Le pasa a él más bien como al testigo de Raskolnikov, Svidrígailov, otro suicida: en aras de complacerse a sí mismos, dejan de conocerse a sí mismos. Hubieran debido saber que no iban a tolerarse el llegar tan lejos. Se matan no por ateos sino por ignorantes ${ }^{61}$.

Es notable en Los Demonios que las ideas que se supone mejor describen el pensamiento del autor (su concepción teísta del universo, su desprecio por los movimientos políticos que inundaban a Rusia de socialismo ateo, su idea de que la sed de inmortalidad es inherente al ser humano), se hallan condensadas finalmente en boca del personaje más ridículo y torpe de la novela, Stepán Trofímovich Verjovensky ${ }^{62}$. ¿Qué argüir a favor de este viejo fantoche, cuando hasta su desvergonzado hijo luce un poco más digno que él? ${ }^{63}$ ¿Acaso no se demuestra con él que ese pensamiento es fruto en primer lugar de la mucha cobardía? Algo que han señalado ya autores como Camus, es que en Dostoievski los personajes oscuros son más interesantes que los luminosos. Pero si bien Aliosha Karamázov y el príncipe Mishkin entregan la bondad como atenuante de su ingenuidad, Verjovensky padre no exhibe nada más que un miedo egoísta como motor de vida; si es él quien se nos quiere demostrar está en lo cierto, debería agregarse que está en lo cierto por razones bastante mezquinas. Por lo menos, deberíamos desconfiar de una verdad que viene en una boca comprobadamente propensa a la pifia.

En el ensayo anterior, me detuve en Kírilov y en cómo su planteamiento es tal que el ateísmo lo lleva a cometer suicidio ${ }^{64}$. Si bien en este caso es innegable que Kírilov se mata únicamente por ser ateo (no especularé que está un poco chiflado, aunque esto es lo que Verjovensky hijo parece creer), voy a subrayar un elemento de mi oración: en este caso. Kírilov se suicida y su propuesta es tal que no hace falta que más ateos lo hagan: su situación es única, lo que debe admitirse es que el ateísmo conduce al suicidio en una ocasión; luego de esta, deja de hacerlo. Kírilov es una especie de Cristo de los ateos, se sacrifica para salvar a los otros; Kírilov no demuestra que el ateísmo conduzca a la muerte, salvo si pensamos que también el caso de Jesús de Nazareth demuestra que la religión cristiana lo hace. Y lo digo de una vez: ¿no es este Kírilov una parodia de Cristo? Matarse para salvar a los demás, pero sin creer en Dios y en la vida eterna, sino más bien creyendo en la nada que aguarda, y resguardando con su acto la libertad humana, no constituye más que una suerte de reverso del actuar de Jesús. Yo, sin embargo, me atrevo a sostener que Kírilov procede con mucha más lógica que Cristo, cuya mentira corrige, y que verdaderamente no se puede comprender: por mucho que el cristianismo lo cacaree como uno de sus dogmas, no puede entenderse por qué Dios debe encarnarse y cometer suicidio para salvar a los hombres. ¿Acaso la Divinidad carece de imaginación como para no tener que recurrir a la barbarie masoquista? ${ }^{65}$

Un personaje aparentemente menor en Los Demonios es la víctima de Verjovensky y su grupo de extremistas, su excompañero en la militancia revolucionaria llamado Shátov. Pero debe andarse uno con cuidado al calificarlo así; después de todo, es aquel cuyo asesinato 
es uno de los móviles de buena parte de la narración. Se le podría identificar nada más que con el príncipe Mishkin en relación con sus ideas acerca de la ortodoxia y del destino de Rusia como pueblo elegido, pero hay una diferencia importante: Shátov no cree en Dios, solo planea confusa y sufrientemente el hacerlo: "Yo... yo creeré en Dios" (1980: 269). El titubeo se explica porque el punto resulta álgido: todo el edificio filosófico y político que defiende Shátov descansa sobre el pilar de la fe, y como ha dicho Stavroguín, "[...] para hacer una salsa de liebre lo primero que se necesita es una liebre; y para creer en Dios hace falta un Dios" (1980: 268-269). Pienso que Shátov es fundamental por cuanto es una versión mucho más combativa que el príncipe Mishkin (al fin y al cabo, un idiota bastante pasivo e inútil) de un pensamiento que Dostoievski defiende. Pero además, lo es por cuanto representa el "padecimiento" de la imposibilidad de la fe, por mucho que se considere esta como necesaria y conveniente: no importa cuán voraz se haya tornado el hambre de la salsa, la liebre se escabulle.

Shátov considera que el socialismo está indefectiblemente destinado al fracaso por su compromiso con la razón, lo cual lo hace incapaz de relacionarse con el corazón de las naciones:

[...] ni un solo pueblo se ha estructurado hasta ahora sobre los principios de la ciencia y de la razón [...] El socialismo [...] ha proclamado, en su declaración de principios, ser una institución atea y asentarse exclusivamente sobre los cimientos de la ciencia y la razón. En la vida de los pueblos, la razón y la ciencia han desempeñado siempre, ahora y desde la fundación del mundo, una función secundaria y accesoria, y seguirán desempeñándola hasta la eternidad. Los pueblos se constituyen y se mueven en virtud de otra fuerza. [...] Es la fuerza de la reafirmación perenne y constante del propio ser y de la negación de la muerte. [...] Es la búsqueda de Dios... (1980: 265-266).

Por supuesto, Shátov piensa que esa nación vigorosa que lleva al Dios verdadero en su sangre y que ha de inyectar ese Dios nuevo en el mundo es la rusa ${ }^{66}$. Y todas estas ideas le vienen, por cierto, de Stavroguín, que es ateo y dice haberlo sido también en el momento de enunciarlas ${ }^{67}$.

Aunque decepcionado porque Stavroguín, en quien tanto él como Verjovensky hijo ven al líder imprescindible, ya no está dispuesto a defender estos planteamientos, Shátov no los abandona; al contrario, abandona la célula socialista de endemoniados y esto le cuesta la vida. Shátov representa a los derrotados, pero derrotados de momento. La esperanza de Dostoievski estriba en que esta situación deje de ocurrir. Mas no se nos olvide: Shátov no consigue creer en Dios, aunque su ideario político y filosófico así se lo exijan ${ }^{68}$.

Es el Diablo el único que aparece en la obra de Dostoievski, si bien con ello no da pruebas contundentes de su existencia ${ }^{69}$. Dios no se manifiesta para no limitar la libertad humana de creer o no creer; por ello, ninguna fe que valga la pena puede ser perfecta: es lo que afirma Tijon cuando admite sus propias dudas (1980: 728) ${ }^{70}$. Por eso hay que trabajar para obtener la solidificación de la fe; no consigue terminar de hacerlo Shátov, lo matan primero. No quiere hacerlo Stavroguín, pese a que Tijon le explica cómo: la penitencia le valdrá lo suficiente: “iSi cree que puede perdonarse a sí mismo y aspira sólo a alcanzar este perdón a través de su sufrimiento, ya cree usted en todo! [...] ¿Cómo ha podido decir usted que no cree en Dios? [...] Dios le perdonará esta incredulidad, pues en verdad venera usted al Espíritu Santo sin conocerlo" (1980: 758). Se trata de que es posible acercarse a Dios incluso si no se cree en su existencia, por la vieja fórmula de la purgación tormentosa, una idea que ya hemos visto cómo rechaza Iván Karamázov. Tal vez más interesantes sean las fórmulas que el starets Zosima le explica a la madre de Lisa para solidificar la fe y la que Shátov recomienda a Stavroguín ${ }^{71}$. 
En el capítulo significativamente titulado "Una dama de poca fe", Libro Segundo de Los hermanos Karamázov, Zosima expone que las buenas obras y el amor al prójimo pueden anteceder a la creencia en Dios y que este recompensará, a la larga, a quien así actúa, obrando milagros (¿de fe?) sobre esta persona: “[...] en el momento mismo en que vea usted horrorizada como, pese a todos sus esfuerzos, no sólo no se ha aproximado al fin (se refiere a la creencia en Dios), sino que incluso parece que se ha alejado de él, en ese mismo instante, se lo predigo, alcanzará usted de pronto el fin y verá claramente sobre sí la fuerza milagrosa del Señor [...]” (1983: 76). Un camino menos sádico que el de Tijon, pero muy incierto: no existe garantía alguna de una recompensa, solo se puede tener fe en llegar a tener fe. A leguas se nota que si el problema es la falta de esta, este camino no se halla dentro de las posibles rutas; en cuanto a Shátov, de lo que se trata es de llegar a Dios por medio del trabajo del mujik, y por eso es que el señorito Stavroguín no puede acercarse $^{72}$. El método también es sospechoso, máxime que, como hemos visto, no parece haber terminado de funcionarle al propio Shátov; de modo que Dostoievski no puede ofrecer fórmulas enteramente fiables para creer en Dios. La liebre, si está, es endemoniadamente escurridiza ${ }^{73}$.

Pero el punto sobre el cual quiero insistir es que estos personajes llenos de dudas sobre la existencia de Dios (Iván Karamázov y Shátov, acaso también Stavroguín ${ }^{74}$ ) pueden creer que esta resulta necesaria para la vida humana sostenible ${ }^{75}$ y para la correcta organización de la sociedad, pero eso no les prueba nada al respecto. La existencia de Dios no tiene relación alguna con su necesidad en las vidas de las personas. Lo conveniente no es igual a lo cierto. Además, la lectura que propongo afirma que la creencia en Dios no resuelve tajantemente los conflictos planteados en las tragedias dostoievskianas; por consiguiente, tampoco se puede asegurar que la creencia en Dios constituye una conveniencia cabal o suficiente para dar la paz a la especie humana. El conflictivo mundo de Dostoievski es mucho más complejo de lo que el elemento "fe" alcanzaría a resolver. Dostoievski sabe más que Dostoievski.

Para terminar, una breve mirada a Dostoievski desde la modernidad, o al menos desde una cierta versión de esta. Hablo ahora desde una noción de ser humano enteramente materialista. Hija de una lectura contemporánea de Darwin, esta noción se sabe también por completo capacitada para explicar los vericuetos complejísimos de la existencia humana sin recurrir a ideas espiritualizantes; de manera que, si acepto que Dostoievski conoce el alma humana, lo estoy afirmando de una forma más bien metafórica. Tal cosa como el dualismo que separa alma o mente de cerebro me resulta sumamente sospechosa.

Iván Karamázov necesita de Dios para culparlo por crear un universo tan desastroso, en el sentido de que está poblado por el sufrimiento injustificado. Señala Claudio Gutiérrez que una de las objeciones más fuertes que pueden hacerse al "argumento del diseño", el cual consiste en deducir la existencia de un diseñador universal, llámese Dios, “[...] a partir del maravilloso y delicado funcionamiento de los seres vivos [...]" (2006: 4), es que existen abundantes excepciones "[...] incompatibles con la perfección atribuida por las religiones al Dios Creador (múltiples deficiencias del cuerpo humano, órganos residuales que no cumplen ninguna función, enfermedades, errores de reproducción que producen toda clase de monstruos, etc.) [...]" (2006: 4). También el sufrimiento de los niños inocentes se podría añadir a esta lista de incompatibilidades, según Iván. El starets Zosima advierte que en la contemplación de la naturaleza encontrará el hombre la fe, en un momento de honda comunión con el entorno ${ }^{76}$. Parece que por un lado está Iván viendo lo malo y por otro Zosima viendo lo bueno.

Pero debe añadirse que Zosima se está cegando en relación con los graves problemas que también presenta la naturaleza, según nos hace patente Gutiérrez, y una visión menos ingenua (o que busque menos el autoengaño y la autocomplacencia) de la naturaleza nos deja 
a Iván y a Zosima viendo lo mismo. Por supuesto, no se trata de que el entorno nos demuestre solo algo malo: se trata de que nos muestra una creación en la cual las consideraciones éticas no tienen relevancia: el "diseño sin diseñador" del universo resuelve perfectamente por qué en la creación de la naturaleza no han intervenido sino el azar y grandes cantidades de tiempo ${ }^{77}$, en un mundo en el cual la presencia de la vida no necesita de esa intuición de lo divino que Zosima pretende y promulga. Así también queda resuelto el problema que tanto atormenta a Iván, cual es, en el fondo, el de la presencia del mal en el mundo:

\begin{abstract}
Darwin procede a desechar todos los fenómenos y causas sobrenaturales pues su teoría de la evolución por selección natural explica la diversidad del mundo en una forma completamente materialista. No necesita ya un Dios diseñador del universo pues todos los aspectos de maravilloso diseño en la naturaleza, blandidos por científicos creyentes anteriores a él, pueden explicarse por selección natural. Es de notar que en esta explicación mecanicista de la naturaleza no ocurre el famoso "problema del mal en el mundo" que los teólogos se ven en la apremiante necesidad de explicar. La nueva concepción predice, con clara simplicidad, que el diseño automático de la selección natural no favorece siempre al ser humano [...]. (Gutiérrez 2006: 9)
\end{abstract}

En cuanto a la libertad humana, que en Dostoievski es un importante don de Dios contra el cual van sus enemigos, el mayor de los cuales es el Gran Inquisidor, tampoco hace falta suponer la existencia de la Divinidad para explicarla, entre otras cosas porque se halla muy en entredicho, pero más aun porque el grado limitado de libre albedrío a que tienen acceso los seres humanos también deriva de las condiciones mecánicas de la máquina que es el cerebro ${ }^{78}$. El libre albedrío es una consecuencia más, perfectamente explicable y en los mismos términos darwinianos, de la evolución. Es ese mundo sin Dios el que provee de libertad, si bien limitada, a los seres humanos ${ }^{79}$.

Y en cuanto a la caída en el abismo de la locura de los personajes que practican el ateísmo (el caso de Iván), también hará falta traer a colación el dictamen de Eric Fromm que nos recuerda Claudio Gutiérrez: "[...] la locura puede entenderse como la religión privada de un paciente, y la religión no es otra cosa que la locura pública de una congregación” (2006: 305). Ya desde el Quijote se sabe que la locura solo se censura cuando la cometen las minorías, pues si las mayorías la practican entonces suele apodársela "verdad" 80 . Si Iván llega a estar loco como ateo, acaso lo estaría más de ser creyente, aunque en este último caso contara con mayor aceptación social ${ }^{81}$.

Así pues, Dostoievski podría visualizarse hoy esencialmente fracasado en cuanto a sus ideas filosóficas primordiales: concepción teísta de universo, defensa de la libertad humana como un don de Dios, identificación del ateísmo con la depravación moral y hasta con la locura, defensa del cristianismo ortodoxo incluso como opción política. Pero no debe pasarse por alto que esto es solo una cara de la moneda. Dostoievski es, además, por otro lado, y me atrevo a decir que principalmente, un escenario textual lleno de dudas: sus ideas van y vienen en el concierto del accionar y de las palabras de sus personajes, y lejos de entronizarse algunas, como la afirmación de la verdad del autor, todas demuestran en el movimiento que alguna imposición solo es obligatoria si uno accede a estar de acuerdo con el autor. Quiero decir que Dostoievski sabe tanto sobre el ser humano que llega incluso a saber más de lo que su propio credo querría saber: conoce que la complejidad de la existencia humana no se resuelve con el ejercicio de la religión, por mucho que esta se conciba de la que uno cree es la mejor forma posible, conoce que el hombre solo por un afán de simplismo puede ver el mundo sin ver errores que atribuidos a un supuesto Dios harían de este un criminal abominable, conoce la indiferencia ética del cosmos, que solo una toma de conciencia voluntaria del ser humano puede remediar. Dostoievski ha intuido, en sus personajes admirables, no importa si son ruines o sublimes, ese conocimiento del hombre que tanto persiguió obtener, incluso cuando no lo complacía. Es por haberse acercado al ser humano, y no a la religión, que debemos seguir admirándolo. 


\section{Notas}

1. Esto he tratado de demostrar en un texto previo: "Los hombres de Dostoievski".

2. Aunque reitero las objeciones de René Wellek. Véase la nota 53 del ensayo citado en la nota 1.

3. Y básicamente por esto Wellek tiene razón al negar que Dostoievski sea un imparcial (Wellek s.f.).

4. Una suerte de "contrademostración": la penitencia de los equivocados demuestra los errores de estos. Este proceso lo sintetiza uno de los títulos más conocidos del autor: Crimen y castigo.

5. Esto se justifica porque, como sostiene Todorov, la única manera de mostrar respeto por un autor es continuar buscando la verdad (sobre el ser humano, en este caso) que él mismo se empeñó en buscar. Este es el genuino respeto que deben inspirarnos los autores que admiramos. Véase Todorov (1991: 150).

6. Ensayos sobre un nuevo humanismo (2006). En la medida en que Dostoievski se consideraba a sí mismo ligado a corrientes de tipo espiritualizante, tiene importancia aquí la aclaración casi redundante de que el darwinismo no lo es para nada. Por ello no podré menos que diferir con Dostoievski y su noción de ser humano, aunque se verá que no por completo. Al valorar lo que parcialmente encontramos aún vigente en el autor, valoramos también su poderosa intuición. Bien dijo Freud que dondequiera que él había ido, un poeta había llegado primero.

7. Véase Florovsky 1982.

8. Antes de ello, sería impropio hablar de iglesia rusa: existía más bien una iglesia bizantina en territorio ruso.

9. Aún en la actualidad: Vladimir Putin asistiendo a los funerales de Yeltsin en la reconstruida iglesia de Cristo Salvador en Moscú nos puede ilustrar.

10. Para muestra, un botón: usaron el latín para el rito durante mucho tiempo.

11. Véase Dostoievski 1983: 405- ss.

12. Digo que "en cierto sentido" porque está muy lejos de mí la idea de que toda moral es relativa y por lo tanto vale lo mismo una que otra. Lo cierto es que debemos comprometernos éticamente, pero eso no quiere decir comprometernos con cierta ética por las razones erróneas (como que hemos nacido en una sociedad particular que defiende tradicionalmente ciertos valores y los considera sagrados e invariables) sino por las razones correctas (como que pensamos y razonamos que hay diferencias cualitativas entre el bien y el mal). Sobre este tema, puede consultarse el interesante libro de Terry Eagleton Más allá de la teoría.

13. No obstante lo cual, y por triste que parezca, en la actualidad tenemos razones para pensar que los protestantismos e islamismos fundamentalistas son todavía peores. Véase Dawkins (2007). ¿Y qué decir recientemente de los sionistas?

14. Es que hay algo en el interior de cada iglesia que quiere negar siempre su propia naturaleza, seguramente porque admitirse como una iglesia más la equipara demasiado con los demás cultos, es decir, relativiza sus valores y sus dogmas (y en esa medida estos pierden fuerza). Un caso curioso: según entiendo, en nuestro medio, los "testigos de Jehová" sostienen que en las otras religiones se asiste a las iglesias; ellos, en cambio, no lo hacen. Para mi asombro, el hecho de llamar a su lugar de reunión "el salón" en lugar de "la iglesia" contribuye a la propagación de tamaño disparate. 
15. ¿Son verdaderas las intenciones de algunos personajes dostoievskianos cuando pretenden la imposición de una iglesia fundida con el estado que rija en Rusia? Iván Karamázov -y así lo hace notar Miúsovparece estar simplemente divirtiéndose cuando propone que los tribunales de estado se conviertan en tribunales eclesiásticos, lo que implica en el fondo el rechazo a la división entre la iglesia y el estado. Pero más allá del cambiante humor con que Iván toca estos temas, quedan personajes muy serios cuando proponen que el ideal del estado debería ser el "elevarse" hasta convertirse en iglesia. Miúsov reacciona indignado: “-Pero, ¿qué significa todo esto en realidad? -exclamó Miúsov como si de pronto estallara-. ¡En la tierra se elimina al Estado y en su lugar se eleva a la iglesia! ¡Esto ya no es ultramontanismo, ya es archiultramontanismo! ¡Ni al papa Gregorio VII se le ocurrió cosa semejante!” Inmediatamente lo corrigen: "- ¡Lo interpreta usted completamente al revés! -replicó severamente el padre Paísi-. No es que la Iglesia se convierta en Estado, compréndalo. Esto sería Roma y su sueño. ¡Sería la tercera tentación del diablo! Al contrario, es el Estado el que se transforma en Iglesia, se eleva hasta la Iglesia y se convierte en Iglesia en toda la tierra, lo cual está diametralmente opuesto al ultramontanismo, a Roma, y a lo que usted ha entendido; es tan solo la gran misión reservada a la ortodoxia en la tierra. Es en Oriente donde esta estrella comenzará a brillar" (Dostoievski 1983: 86).

16. Camus s.f., capítulos II y IV, sobre todo.

17. "Si nada es cierto, si el mundo carece de regla, nada está prohibido; para prohibir una acción se necesita, en efecto, un valor y una finalidad. Pero, al mismo tiempo, nada está autorizado; se necesitan también un valor y una finalidad para elegir otra acción. [...] Una lógica más profunda reemplaza entonces al 'si nada es cierto, todo está permitido' de Karamázov por un 'si nada es cierto, nada está permitido'. Negar que una sola cosa esté prohibida en este mundo equivale a renunciar a lo que está permitido” (Camus s.f.: 64).

18. Con los consiguientes roces, eso sí, que esto inevitablemente acarrea al tratar con tradiciones diferentes de la nuestra. Pero se trata de atenerse a la moral divina, incluso si esto produce la guerra religiosa.

19. ¿Por qué motivación racional se combatiría de una manera tan cruenta y durante tanto tiempo para hacerse de un territorio inhóspito como el que se pelean israelitas y palestinos? Cualquiera que no creyera delirantemente que Dios le ha indicado que debe vivir en medio de un desierto horripilante, hace mucho habría dejado la disputa y se habría instalado con más comodidad en alguna otra parte del ancho planeta. Por supuesto que este comentario peca de simplista, en la medida en que desconoce los intereses geopolíticos que se defienden en Medio Oriente (Israel es el gendarme de los Estados Unidos en una región que le interesa sobremanera por el petróleo cercano), pero el punto es que muchos de quienes luchan allí lo hacen desconociendo esos intereses y apegándose únicamente al mandato religioso. Son precisamente estos ingenuos los que se matan.

20. ¿Es cierto que necesitamos de la amenaza divina para no convertirnos en delincuentes? Richard Dawkins se interesa por el tema en El espejismo de Dios y hace ver que no hay ninguna relación estadística entre las creencias religiosas y la comisión de delitos: es decir, nada hay que compruebe que la fe en Dios nos aleja del delito y el ateísmo nos lance hacia él. De hecho, hay datos interesantes en el sentido contrario: "Gregory S. Paul, en el Journal of Religion and Society (2005) comparó sistemáticamente 17 países económicamente desarrollados y llegó a la devastadora conclusión de que 'las tasas más altas de veneración y fe en un creador se relacionan con las tasas más altas de homicidio, de mortalidad juvenil y temprana, de tasa de infecciones, de enfermedades de transmisión sexual, embarazos adolescentes y aborto en democracias prósperas"” (Dawkins 2007: 248).

21. El clásico ensayo freudiano Dostoievski y el parricidio describe la personalidad del autor ruso como sádica y masoquista. No estoy interesado en la supuesta neurosis del autor, pero sí creo pertinente para mis propósitos escuchar la siguiente opinión de Freud: "Podemos decir que Dostoievski no se vio jamás libre de remordimientos por su primitivo propósito parricida. Tales remordimientos determinaron 
también su actitud en los otros dos sectores en los que la relación paterno-filial da la norma; esto es, ante la autoridad estatal y ante la creencia en Dios. En el primero llegó a una plena sumisión al padrecito zar, el cual había representado con él una vez, en la realidad, la comedia de la muerte que sus ataques le presentaban con tanta frecuencia. La penitencia logró en este punto un predominio absoluto. En el terreno religioso le quedó mayor libertad. Según informes de cierta garantía, osciló durante toda su vida entre la fe y el ateísmo. Su gran inteligencia le hacía imposible ocultarse las enormes dificultades mentales que suscita la fe. Repitiendo individualmente una evolución histórica, esperaba hallar en el ideal cristiano una salida y una redención y utilizar sus sufrimientos mismos como base de una aspiración a un papel de Cristo. Si en conjunto no llegó a alcanzar la libertad y se hizo reaccionario, fue porque la culpa filial, generalmente humana, en la que se basa el sentimiento religioso, alcanzó en él una intensidad superindividual, permaneciendo inaccesible incluso a su gran inteligencia" (Freud 1974: 3011).

22. La verdadera tragedia de don Juan es esta: no creer que es posible el amor, por lo que nada lo conduce a una conducta ética solidaria.

23. Consúltese la nota 3 de "Los hombres de Dostoievski".

24. Un error al que quizá Bajtín nos ha inducido es poner atención solo a las voces de las novelas de Dostoievski, y olvidarnos de que los personajes son voces y acciones.

25. Dostoievski también describe una de esas fantasías, creo que común entre los artistas, y que probablemente lo afectó a sí mismo, en una obra menor, Humillados y ofendidos: "[...] siempre me resultaba más agradable planear mis novelas y fantasear de qué modo iba a escribirlas que el hecho mismo de escribirlas" (1977: 7). Dato interesante: se trata de la primera página de la novela. Es decir, es una confesión ocurrida en el momento en que el texto posiblemente existía solo como un proyecto irreal en la cabeza del autor. La paradoja del arte literario es que es una fantasía del autor que, en el momento de exteriorizarse, se realiza como fantasía.

26. La prédica de don Quijote acerca de su heroísmo caballeresco es tan constante, o más, como lo son sus actos heroicos.

27. Es como si don Quijote hiciera un pequeño ensayo secreto que lo confirmara como caballero andante antes de salir de su casa. Algo de eso hay, pero lo único que prueba -y solo una vez, por aquello de que las ilusiones son frágiles- es su celada: "Limpiólas y aderezólas lo mejor que pudo (sus armas); pero vio que tenían una gran falta, y era que no tenían celada de encaje, sino morrión simple; mas a esto suplió su industria, porque de cartones hizo un modo de media celada que, encajada con el morrión, hacían una apariencia de celada entera. Es verdad que, para probar si era fuerte y podía estar al riesgo de una cuchillada, sacó su espada y le dio dos golpes, y con el primero y en un punto deshizo lo que había hecho en una semana; y no dejó de parecerle mal la facilidad con que la había hecho pedazos, y, por asegurarse de este peligro, la tornó a hacer de nuevo, poniéndole unas barras de hierro por de dentro, de tal manera, que él quedó satisfecho de su fortaleza y, sin querer hacer nueva experiencia de ella, la diputó y tuvo por celada finísima de encaje" (Cervantes 2005: 31). El destacado es mío: quiero hacer notar que don Quijote paradójicamente fue más prudente que Raskólnikov: no constató demasiado la solidez de sus fantasías antes de lanzarse a ellas de lleno. Acaso adivinaba que no resistirían una prueba intensa; la ausencia de esta intuición, a la larga, le costó al ruso ocho años de trabajos forzados en Siberia: como sabemos, se le hizo añicos la "celada".

28. Son otros quienes hacen ver las virtudes de la conducta de Raskólnikov. En consonancia con aquello de que tu mano izquierda no debe saber lo que hace la derecha.

29. Alonso Quijano ha sido Alonso Quijano el Bueno antes de ser don Quijote. 
30. El problema de por qué se produce la confesión de Raskólnikov sigue abierto, pues en el texto no se da una explicación clara al respecto. Yo me inclino por pensar que no hubo en el asesino temor de ser descubierto, sino de convertirse en un nuevo Svidrígailov: un ser que, dejándose llevar por las exigencias de su egoísmo, termina hundido en lo más sórdido. Creo que Raskólnikov, al conocer del suicidio de Svidrígailov, entendió que debía separarse de su discurso seudonapoleónico para seguir otro camino, que entonces no sabe cuál es. Después se hace cristiano, pero solo porque ya estaba inclinado a una ética solidaria que el cristianismo sabrá presentarle por medio de Sonia.

31. Si bien Aliosha aclara: "Eso es Roma, y aún no toda Roma; sería mentira afirmarlo así, eso es lo peor del catolicismo, son los inquisidores, los jesuitas [...]" (1983: 320).

32. "El poeta quiso, por lo visto, combinar en una imagen excepcional el grandioso concepto del amor caballeresco y platónico medieval tal como lo entendía el caballero puro y magnánimo. [...] El caballero pobre es don Quijote, solo que serio, y no cómico" (Dostoievski 2004: 271).

33. Miguel de Unamuno insiste en ello, a veces un tanto sospechosamente. Por momentos, la comparación es tan forzada que uno no sabe si Unamuno bromea.

34. Transcribo las pertinentes explicaciones del traductor Augusto Vidal: “'Bendito', en ruso 'yuródivi', palabra con que los rusos designan a la persona enajenada de nacimiento que lleva una vida ascética y a cuyos actos y palabras inconscientes se da a veces un sentido profundo e incluso profético. 'Yuródivi' se traduce también por 'imbécil', 'idiota', 'inocente', 'simple'. Creemos preferible el vocablo 'bendito' porque recoge el matiz religioso de la palabra rusa, aunque pierda en gran parte el de 'persona enajenada"” (Dostoievski 1983: 32).

35. De nuevo Unamuno viene al caso: recordemos a Blasillo el bobo, el personaje tal vez más genuinamente creyente de San Manuel bueno, mártir.

36. Pero bueno, esto viene de atrás. El árbol del conocimiento era el prohibido y de hecho el evangelio desvaloriza el entendimiento. Dostoievski era muy consciente de ello, y así nos lo hace ver Matl (s.f.: 54):

Dostoievski, como observó ya certeramente André Gide, imprime a su desvalorización evangélica del entendimiento el acento de un mensaje redentor proclamado por los niños, las mujeres del pueblo, los ignorantes, los incultos, el hombre próximo a la Naturaleza, por todos aquellos, en fin, a los que el saber no ha privado aún de la lozana originalidad, en los que vive aún el entendimiento original, el entendimiento del corazón (príncipe Mishkin).

¡Menudo grupo de sabios! ¿Será necesario hacer patente la certidumbre de que el cristianismo desvaloriza el saber porque este siempre termina por descreer de sus absurdos dogmas?

37. En su primera juventud, antes del tiempo en que inicia de la novela, ya había andado Mishkin por ahí. Lo suyo al final es un retorno: el supuesto santo no solo termina idiota, también se origina de ese modo. Se me ocurre un buen título para un artículo al respecto: "Santidad cristiana y subnormalidad".

38. Lejos de mí el intentar una justificación del femicidio. El acto de Rogoyín es un crimen mayúsculo, como quiera que se lo vea. Ahora bien, toda la relación de él y Natasha Filipovna se basaba en la violencia física y sobre todo psicológica por parte de ambos.

39. Véase Dostoievski 2004: 240-ss. 
40. ¿Será porque se da cuenta de que el príncipe no se da cuenta de esto que Rogoyín, personaje normalmente nada festivo, aquí se ríe hasta las lágrimas? De cualquier manera, debe anotarse a su favor que él no intentó justificar su crimen de este modo.

41. ¿Debería la religión considerarse una adicción? (Véase Dawkins 2007) Sabido es que los adictos pueden controlarse, pero no curarse; por ello, el alcohólico en recuperación no tolera el convertirse en bebedor social: una sola gota de licor lo arrojaría de nuevo a la enfermedad; del mismo modo, Ippolit no consigue arrancarse una creencia que siempre se las arregla para regresar a su mente, y por ello vuelve a las andadas de la fe que ha rechazado.

42. “[...] durante toda su vida, Fiódor Pávlovich fue amigo de hacerse el interesante, de representar ante una persona, súbitamente, un papel inesperado, a veces sin necesidad alguna e incluso en perjuicio de sí mismo [...]" (1983: 20).

43. De por sí, esa es la forma como creen bastantes personas en nuestros días, ya muy poco amantes de las amenazas religiosas atronadoras. Se apresuran a concebir el tipo de Dios que más les agrada y lo dan por un hecho. Curiosa y frecuente autocomplacencia moderna, que en su torpe lógica casi me hace desear el retorno al rigor de otras épocas en las que, al menos, se debía sacrificar algo en los placeres personales para creer en Dios.

44. No se me pasa que afirmo ahora lo contrario de lo dicho como hipótesis de lectura en mi primer ensayo, "Los hombres de Dostoievski". Lo cierto es que la contradictoria obra de Dostoievski admite ambas lecturas; de hecho, mi intención en este segundo texto ha sido demostrar que ambas se sostienen: Dostoievski combate a Dostoievski.

45. Concedo pues que la castidad se puede contemplar dentro de esta categoría, si bien en mi opinión la carencia de una saludable vida sexual más bien suele motivar conductas muy poco virtuosas.

46. Dostoievski 1983: 303.

47. Iván recusa el método de Dios; este no es bueno solo porque además de crear dolor a los otros lo crea para sí mismo: al contrario, así visto resulta peor. Iván se burla: “¡Ah, te refieres al "Único sin pecado” y a su sangre! [...] me sorprendía que tardaras tanto en referirte a Él, porque generalmente, en las discusiones, los de tu condición en seguida lo sacan a relucir" (1983: 302). No comparto la bastante sorprendente opinión de Camus acerca de que todos estamos dispuestos a admitir un método doloroso si el resultado es bueno (como, por ejemplo, cuando se recibe tratamiento por una enfermedad); piénsese como Iván que Dios, en su omnipotencia y omnisapiencia, bien hubiera podido idear caminos menos torturantes.

48. Y que también podríamos relacionar con el hecho de que los valores provienen del ser humano, y no de Dios.

49. Esta postura de Aliosha, según Camus, cala en Iván, algo de lo cual no estoy seguro. Para mí, Iván sigue viviendo por causa de su latente lascivia karamazoviana. Véase Camus s.f.: 50-51.

50. El hecho ocurre durante la entrevista con Zosima:

“-Permítanme -exclamó de pronto Dimitri Fiodórovich, gritando-, por si lo he oído mal: "El crimen no sólo ha de ser considerado lícito, sino que incluso ha de ser reconocido como la salida más necesaria y juiciosa de la situación en que se encuentra todo ateo.” ¿Es así?

“-Exactamente así -dijo el padre Paísi. 
“-Lo recordaré.

"Dichas estas palabras, Dimitri Fiodórovich se calló tan repentinamente como había terciado en la conversación[...]”. (1983: 90)

51. Pero que, admítase, él estuvo a punto de ejecutar.

52. Del segundo hijo de Fiódor Karamázov habría que decir que loco, pero no tonto.

53. Así declara: "En cuanto a mí, hace tiempo que he decidido no pensar en si es el hombre el que ha creado a Dios o Dios al hombre" (1983: 289).

54. Por cierto que Dimitri considera poco probable la muerte del hermano Iván: "Es él quien ha de vivir y no nosotros" (1983: 918).

55. Este pasaje ha de haber sido el favorito de Freud.

56. Véase Jakub Bomba, "Stavrogin's Quest. Descriptions of the major stations of Stavrogin's journey to find God and eventual downfall" (s.f.).

57. Shátov lo interroga:

[...] ¿Es cierto que usted perteneció en Petersburgo a una bestial asociación secreta, dedicada a la lujuria? [...] ¿Es cierto que el marqués de Sade hubiera podido aprender de usted? ¿Es verdad que se dedicaba a engatusar y a pervertir niños? [...] ¿Es cierto que llegó a afirmar que no hacía distinción entre cualquier acto brutal y voluptuoso y la mayor de las proezas, aunque fuese el sacrificio de la vida en aras de la humanidad? ¿Es cierto que encontraba usted en los dos sexos la misma belleza y el mismo deleite? (1980:270).

Stavroguín niega solo el haber abusado de niños. A este punto no tolera llegar.

58. 1980: 264 -ss.

59. Suponiendo, insisto, que alguna vez lo tuvo. Tanta ambigüedad proviene de que Stavroguín lo niega, pero Shátov no acepta que el primero no haya sido sincero al hacer declaraciones como la última citada.

60. Soy consciente, sin embargo, de que la existencia de Dios implicaría la del bien y del mal, algo que Stavroguín ha negado. Pero el punto es que si hay un gran aburrimiento, esto puede impulsar actos que sean malos pero necesarios para combatir el hastío.

61. Conviene, sin embargo, distinguir: Svidrígailov sí hubiera podido seguir viviendo de haber tenido éxito en su persecución de la hermana de Raskólnikov, Stavroguín no lo consigue luego de haber consumado su crimen con una niña; es decir, que el primero se mata porque su apego al mal es tal que sin este no logra vivir, mientras que el segundo lo hace por el remordimiento, que por cierto se le concreta en las visitas que le hace el Diablo (1980: 726). Lo que ambos comparten estriba en que no supieron cuál es el punto al cual no debían llegar en el camino hacia el mal, si deseaban preservar su propia existencia.

62. 1980: 692-ss.

63. Piotr Stepánovich al menos ofrece algún brillo satánico, si bien no a la altura de Stavroguín, sí por lo menos como para ser el líder de hecho de "los demonios" (entiendo que acá la traducción también podría ser "los endemoniados" o "los posesos". Se refiere obviamente a los poseídos por el demonio en el pasaje citado en epígrafe (Lucas VII, 32-36)). 
64. "Los hombres de Dostoievski": allí detallo los pasos lógicos que van de la inexistencia evidente de Dios al suicidio de Kírilov. Breve resumen aquí, que sacrifica parcialmente el rigor del planteamiento: Kírilov se mata para probar a los hombres que son libres ante la muerte, dado que Dios no existe y esto los aterra. Pero una vez que Kírilov se ha matado, los demás no necesitan ni mentirse con que son inmortales (el embuste de Cristo) ni atormentarse por no serlo: pueden ejercer su libertad para vivir, no ya para morir.

65. Perdón por repetirme. Remito a Iván según la nota 48.

66. Dos aclaraciones: Primero, "nuevo" no quiere decir que no sea el mismo Jesucristo, pero se trata de la versión genuina de este, que sí sería nueva para el mundo no auténticamente ruso. Y lo segundo es que Shátov se emociona con la noción de un Dios verdadero a la rusa, pero sin creer, como hemos visto, en Él. En esta línea, recuerdo el chiste de un español ateo que, ante la insistencia de un protestante para hacerlo abrazar su fe, le replicó: "Pero hombre, si no creo ni en la religión católica, que es la verdadera."

67. “- ¿Es usted ateo? ¿Profesa ahora el ateísmo?

-Sí.

- ¿Y entonces? (Se refiere Shátov al momento en que Stavroguín explicaba todo esto)

-Exactamente igual que ahora" (1980: 264).

Ahora bien, como he dicho, no se sabe cuán sincero es Stavroguín al hacer estas declaraciones. A ratos parece estar jugando con Shátov.

68. Es grande la tentación de identificar a este personaje con el autor.

69. Tanto en el caso de Iván Karamázov como en el de Stavroguín se defiende fuertemente la posibilidad de que el personaje que recibe a Satanás esté alucinando. Ahora bien, no faltan otros personajes, muy en sus cabales, como el piadoso Tijon, que sí creen en la existencia real de ese espíritu maligno. No consigo dilucidar la opinión de Dostoievski al respecto, pero supongo que con tantas dudas como albergaba acerca de la existencia de Dios, la del Diablo le ha de haber resultado una creencia mucho más difícil, puesto que en buena medida solo pueden creer en este quienes ya poseen certeza del primero. Solo en una reciente película no tan buena, El exorcismo de Emily Rose, la protagonista, una pobre enferma mental agobiada por la fantasía de su posesión demoniaca y alejada del tratamiento médico correcto por la intervención criminal de un cura católico, llega a explicarse el por qué de su sufrimiento permitido por Dios y la Virgen como una forma que tiene la Divinidad para manifestar su existencia: viendo que el Diablo existe, aceptarán las personas que hay un Dios también. Pero yo no supongo que Dostoievski haya pensado así: tanto sadismo en Dios y la Virgen lo habrían escandalizado incluso a él (o por lo menos, es seguro que Iván sí habría puesto el grito en el cielo).

70. Esta lectura del cristianismo, que implica la ausencia del milagro, no deja de forzar la interpretación de los evangelios: Jesús hace milagros muchas veces y en público. Decir que Dios no los ejecuta ahora para no limitar nuestra libertad de creer equivale a decir que, en vida de Jesús, este irrespetaba esa misma libertad: ¿acaso a Lázaro, que se levantó de la tumba, le podía quedar algún tipo de duda?

71. Debería sospecharse que el propio Shátov la ha empleado durante su estancia en América, pero en tal caso con un éxito apenas parcial, puesto que continúa sin creer en Dios. Asumiré que se nos sugiere que se hallaba Shátov todavía en camino de llegar a la perfección como creyente.

72. No hay que olvidar que Stavroguín ha sido el chico consentido de su madre, una poderosa y rica mujer, que no deja de preocuparse por él en ningún momento, si bien esa preocupación la ha llevado a menudo 
al yerro más rotundo, como cuando puso al pequeño niño al cuidado del preceptor Verjovensky. Se insinúa que esta primera influencia nociva fue insuperable incluso para el Stavroguín adulto: "Stepán Trofímovich supo tocar las fibras más íntimas del corazón de su pequeño amigo y suscitar en él la primera sensación, todavía imprecisa, de esa sagrada nostalgia que un alma selecta, al conocerla siquiera una vez, jamás trocaría luego por una satisfacción barata [...]. Pero lo cierto es que anduvieron acertados al separar, aunque tardíamente, al alumno y al preceptor" (1980: 44).

73. Woody Allen corrige a Einstein con jovialidad: Dios no está jugando a los dados, sino a las escondidas.

74. No cuento a Kírilov, que es un ateo sin dudas, ni a Aliosha o al príncipe Mishkin, creyentes, ni a otros menos involucrados al respecto pero sobre los cuales he tratado aquí, como Verjovensky padre, Karamázov padre, Dimitri, Smerdiákov.

75. Sostenible en el sentido de que no desemboca en la desesperación ni en la depravación.

76. He detallado el proceso, si bien no de forma original pues me baso en Neuhaüser (1986), en mi ensayo "Los hombres de Dostoievski".

77. “(El) concepto (de Daniel Dennett) de "diseño sin diseñador”, a base de las restricciones que impone cada diseño casual en la explosión combinatoria de posibilidades ulteriores, resolvía el problema de la inverosimilitud de que la simple casualidad fuera tan productivamente creadora como lo revelaba la vida" (Gutiérrez 2006:5). No intentaré explicar aquí los pormenores del "diseño sin diseñador", que se pueden consultar en Dennett o en Gutiérrez.

78. Véase Gutiérrez 2006: 234-ss.

79. Gutiérrez traduce a Crick, quien se atreve incluso a sostener que la voluntad y el libre albedrío se pueden "ubicar" como fenómenos propios de ciertas partes del cerebro del primate humano. Véase Gutiérrez 2006: 270-271.

80. Así, cuando todos en la venta convienen en llamar "yelmo de Mambrino" a la antaño "bacía de barbero", es el barbero quien ve metido en problemas.

81. Tómese en cuenta que Iván se siente más aceptado cuando, ante los monjes compañeros de Zosima, se refiere a la unión de la iglesia ortodoxa con el estado. Es decir, cuando anda más equivocado, pues entonces se acerca más al desdén hacia el pensamiento racional. Véase al respecto a Gutiérrez 2006, el apartado titulado "Las trampas del simbolismo y su superación", 310-311.

\section{Bibliografía}

Bajtín, Mijaíl. 1988. Problemas de la poética de Dostoievski (Trad. Tatiana Bubnova). México: Fondo de Cultura Económica.

Berdiaev, Nicolás. 1978. El espíritu de Dostoievski (Trad. Marcela Solá). Buenos Aires: Carlos Lohlé.

Berry, Thomas. 1981. Dostoievski and Spiritualism. http://www.utoronto.ca/tsq/DS/02/043.shtml. Consulta: 1 de abril de 2007. 
1985. Dostoevsky and Socrates: The Underground Man and the "Allegory of the Cave”. http://www. utoronto.ca/tsq/DS/06/157.shtml. Consulta: 1 de abril de 2007.

Blanco Sarto, Pablo. 2003. Los Karamázov discuten. http://www.unav.es/iae/publicaciones/ karamazov.discuten.pdf. Consulta: 20 de julio de 2009.

Bomba, Jakub. 2005. Faith Comparison of two major characters, Ivan Karamázov and Stavrogin . http://www.fyodordostoevsky.com/essays.php. Consulta: 11 de abril del 2007.

s.f. Stavrogin's Quest. Descriptions of the Major Stations of Stavrogin's Journey to Find God and his eventual downfall. http://www.fyodordostoevsky.com/essays.php. Consulta: 11 de abril del 2007.

Cadot, Michel. 1983. L'Occident de Versilov. http://www.utoronto.ca/tsq/DS/04/013.shtml. Consulta: 15 de abril del 2007.

Camus, Albert. 1983. El mito de Sísifo. Madrid: Alianza.

s.f. El hombre rebelde. Santo Domingo: Alfa Omega.

Cantrell, Dan. 1996. Dostoievski and Psychology. http./www.community.middlebury.edu/beyer/ courses/previous/ru351/studentapapers/psychology.shtml. Consulta: 2 de marzo del 2007.

Cassedy, Steven. 1982. The formal problem of the Epilogue in "Crime and Punishment": the Logic of Tragic and Christian Structures. http://www.utoronto.ca/tsq/DS/03/171.shtml. Consulta: 5 de abril del 2007.

Cervantes, Miguel de. 2005. El ingenioso hidalgo don Quijote de la Mancha. Madrid: Real Academia Española.

Dawkins, Richard. 2007. El espejismo de Dios (Trad. Regina Hernández Weigand). Madrid: Espasa Calpe, S.A.

Dostoievski, Fedor. 1973a. El adolescente (Trad. Mariano Orta Manzano). Barcelona: Juventud. 1973b. Recuerdos de la casa de los muertos (Trad. José Baeza). Barcelona: Juventud. 1976. Las noches blancas. San José: Editorial Costa Rica.

1977. Humillados y ofendidos. Madrid: Espasa-Calpe.

1980. Los demonios (Trad. Luis Abollado). Barcelona: Bruguera.

1981. Crimen y castigo (Trad. José Fernández). Barcelona: Juventud. 
1982. El jugador (Trad. Victoriano Imbert). Barcelona: Bruguera.

1983. Los hermanos Karamázov (Trad. Augusto Vidal). Barcelona: Bruguera.

2004. El Idiota (Trad. Alex Shantytown). Buenos Aires: Libertador.

Eagleton, Terry. 2005. Después de la teoría (Trad. Ricardo García Pérez). Barcelona: Debate.

Eco, Umberto. 1975. Obra Abierta. Barcelona: Lumen.

1981. Lector in Fabula. Barcelona: Lumen.

Florovsky, G. 1982. Teología mística de la Iglesia de Oriente. Barcelona: Herder.

Foncelle, Marie Thérèse. 1987. Les techniques narratives dans Saint Manuel le Bon, Mártir de Unamuno et "Le Grand Inquisiteur" de Dostoievski. http://www.utoronto.ca/tsq/ DS/08/155.shtml. Consulta: 18 de abril del 2007.

Freud, Sigmund. 1974. Dostoievski y el parricidio. Barcelona: Alianza.

Gourg, Marianne. 1987. Dombrovskij commentateur de la Légende du Grand Inquisiteur dans la Faculté de l'Inutile. http://www.utoronto.ca/tsq/DS/08/161.shtml. Consulta: 6 de abril de 2007.

Gutiérrez, Claudio. 2006. Ensayos sobre un nuevo humanismo. San José: Editorial EUNED.

Hackel, Sergei. 1982. Dostoevsky (1821-1881): Prophet manque? http://www.utoronto.ca/tsq/ Ds/p7/135.shtml. Consulta: 4 de abril del 2007.

Hanak, Miroslav. 1988. Dostoevsky's Diary of a Writer: A Vision of Plato's Erotic Immortality. http://www.utoronto.ca/tsq/DS/09/091. Consulta: 8 de abril del 2007.

Herbert, Carrie. 2003. The End of Innocence: Good within Evil. http://www.fyodordostoevsky. com/essays.php. Consulta: 12 de abril del 2007.

Igartua Ugarte, Iván. 1997. "Dostoievski en Bajtín: raíces y límites de la polifonía". EPOS. 13: 221-235.

Jones, Malcolm V. 1986. "The Legend of the Grand Inquisitor": The Supression of the Second Temptation and Dialogue with God. http://www.utoronto.ca/tsq/DS/07(123shtml. Consulta: 2 de abril del 2007.

Kiskaddon, Elisa. 1996. Dostoievski and the problem of God. http.//www.community.middlebury.edu/ beyer/courses/previous/ru351/studentpapers/God.shtml. Consulta: 29 de marzo del 2007. 
Kjetsaa, Geir. 1983. Dostoevsky and His New Testament. http:www.utoronto.ca/tsq/DS/04/095. shtml. Consulta: 10 de abril del 2007.

Knapp, Liza. 1987. The Fourth Dimension of the Non-Euclidean Mind: Time in Brothers Karamázov o Why Ivan Karamázov's Devil Does Not Carry a Watch. http://www. utoronto.ca/tsq/DS/08/105.shtml. Consulta: 10 de abril de 2007.

Korkonosenko, Kiril. s.f. "La novela "San Manuel Bueno, mártir" de Unamuno y la "Leyenda del Gran Inquisidor" de Dostoievski”. http://hispanismo.cervantes.es/documentos/ korkonosenko.pdf. Consulta: 25 de julio de 2008.

Leatherbarrow, William J. 1982. Apocalyptic Imagery in “The Idiot” and “The Devils”. http:// www.utoronto.ca/tsq/DS/03/043.shtml. Consulta: 28 de marzo del 2007.

López García, Guillermo. 1998. La división del yo en los personajes dostoievskianos: el caso de El Doble. Actas de las II Jornadas de rusistas españoles., Valencia, Universidad de Valencia, 148-156.

Martínez, Isabel. s.f. Dostoievski frente al nihilismo. http://www.cuenta y razon.org/revista/ pdf/124/Num124.006.pdf. Consulta: 30 de julio de 2008.

Martinova, Bela. s.f. La enfermedad en Dostoievski. http://www.cuentayrazon.org/revista/ pdf/137/Num137.001.pdf. Consulta: 1 de agosto de 2008.

Matl, Josef. s.f. Dostoievski y la crisis de nuestro tiempo. http:/www.cepc.es/rap/publicaciones/ revistas/z/rep.057.034.pdf. Consulta: 1 de agosto del 2008.

Miscin, Daniel. 2007. Some Remarks on the Theodicy of Ivan Karamázov. http://www. fyodordostoevsky.com/essays.php. Consulta: 11 de abril del 2007.

Morley, Bob. 2007. The Theme of Demons. http://www. fyodordostoevsky.com/essays/bmorley.htm. Consulta: 4 de abril de 2007.

Natov, Nadine. 1987. The ethical and structural significance ofe the three temptations in The Brothers Karamázov. http://www.utoronto.ca/tsq/DS/08/003.shtml. Consulta: 9 de abril del 2007.

Neühauser, Rudolf. 1986. A Contemporary Reading of Book VI, “A Russian Monk”. http:// www.utoronto.ca/tsq/Ds/p7/135.shtml. Consulta: 7 de abril de 2007.

Patterson, David. 1987. Dostoievski Poetics of Spirit: Bakhtin and Berdiaev. http://www. utoronto.ca/tsq/DS/08/219.shtml. Consulta: 13 de abril del 2007. 
Rasovic, Savic. 1996. Dostoievski and Social Issues. One Possible Answer: God. http.//www. community.middlebury.edu/beyer/courses/previous/ru351/studentpapers/Social.shtml. Consulta: 29 de marzo del 2007.

Rhodes, Joseph David. 1988. Dostoievski: Christian Mystic and Social Philosopher. Concordia Teachers College, History 451, EE.UU.

Smokti, Eugenia. 2001. "La sed de creer produce herejía: reflexiones sobre la leyenda del Gran Inquisidor de F.M. Dostoievski”. Revista de la Inquisición. 10: 259-282.

Terras, Víctor. 1985. Dostoievski's Detractors. http://www.utoronto.ca/tsq/DS/06/165.shtml. Consulta: 7 de abril del 2007.

Todorov, Tzvetan. 1991. Crítica de la crítica. Barcelona: Paidós.

Townsend, James. 1996. Dostoevsky and his Theology. http://faithalone.org/journal/1997ii/ townsend.html. Consulta: 15 de abril del 2007.

Uhler, Austin. 2003. Truth vs. Illusion. On the Nature of Reality in "Crime and Punishment. http://www.fyodordostoevsky.com/essays.php. Consulta: 11 de abril del 2007.

Vlavid, Slobodanka. 1988. Dostoevsky's Major Models as Semiotic Models http://www. utoronto.ca/tsq/DS/ 09/157.shtml. Consulta: 6 de abril del 2007.

Ward, Bruce. 1986. Dostoevsky's Critique of the West. The Quest for the Earthly Paradise. Ontario: Wilfred Laurier University Press.

Wellek, René. s.f. Bakhtin's view of Dostoevsky: "Polyphony” and "Carnavalesque”. http:// www. utoronto.ca/tsq/DS/o1/031.shtml. Consulta: 4 de abril de 2007. 